\title{
EFFLUENT ORGANIC MATTER (EFOM) IN WASTEWATER: CONSTITUENTS, EFFECTS AND TREATMENT
}

\author{
H.K. Shon ${ }^{1}$, S. Vigneswaran ${ }^{1}$ and S.A. Snyder ${ }^{2}$ \\ ${ }^{1}$ Faculty of Engineering, University of Technology, Sydney, P.O. Box 123, \\ Broadway, NSW 2007, Australia \\ ${ }^{2}$ Department of Research and Development, Southern Nevada Water Authority, \\ 1350 Richard Bunker Avenue, Henderson, Nevada 89015, USA
}

\begin{abstract}
Wastewater reuse is being increasingly emphasized as a strategy for conservation of limited resources of freshwater and as a mean of safeguarding the aquatic environment due to contaminants present in wastewater. Although secondary and tertiary treated wastewater is often discharged into surface waters, it can not be used for reuse purposes without further treatment. One of the parameters of concern for human and environmental health is components of organic matter originating from wastewater treatment plant (WWTP) effluents. This effluent organic matter (EfOM) should be carefully characterized in order to find an optimum treatment method for water reuse. This review presents the components of EfOM present in WWTP effluents and various treatment methods that may be employed for reduction of EfOM. These processes include flocculation, adsorption, biofiltration, ion exchange, advanced oxidation process,
\end{abstract}


and membrane technology. The removal efficiency is discussed in terms of removal of total organic carbon, endocrine disrupting chemicals (EDCs), pharmaceuticals and personal care products (PPCPs), different polarity fractions (such as hydrophobic and hydrophilic) and molecular weight distribution of organic matter.

Keyword: Effluent organic matter; Biologically treated sewage effluent; Wastewater reuse; Characteristics; Treatment; Flocculation; Adsorption; Ion exchange; Biofiltration; Advanced oxidation process; Membrane technology; Molecular weight distribution

\section{Introduction}

Wastewater treatment is employed as an action to protect the quality of limited freshwater resources and therefore make it more acceptable for beneficial reuse. However, achieving this objective remains elusive as the total discharge of biologically treated sewage effluent (BTSE) is continually on the rise due to increasing population and urbanization. Wastewater reclamation has been recognized as one of the most effective ways of increasing the availability of limited freshwater and at the same time, the use of reclaimed water can reduce the demand for freshwater. For the purpose of wastewater reclamation/reuse, it is imperative to study the characteristics of effluent organic matter (EfOM) in the BTSE in detail in order to design effective treatment methods. 


\section{Characterization of Effluent Organic Matter in Wastewater}

\subsection{Overview of EfOM}

The systematic treatment of wastewater was started in the late 1800s and early 1900s (Tchobanoglous and Burton, 1991). For the last two centuries, wastewater treatment has continually been developed to meet strict disposal standards. Recently, wastewater for reuse is being increasingly emphasized as a strategy for conservation.

Although many previous researchers have worked extensively on natural organic matter (NOM) in surface waters, there have been few studies related to EfOM in wastewater. This is probably due to the diverse characteristics of wastewater which vary by place and season. However, as concern related to water reuse increases, an interest in characterizing the EfOM has become more important.

The composition of EfOM is a combination of those of natural organic matter (NOM), soluble microbial products (SMPs) and trace harmful chemicals. Most of the NOM originates from drinking water, which is one of major components in wastewater, while SMPs come from biological treatment with the WWTP and non-biodegradable organic matter. Of particular interest are recalcitrant organic chemicals which are resistant to biodegradation, and thus challenging to remove during typical wastewater treatment. Some micro-contaminants associated with wastewater effluent may cause adverse impacts to aquatic and human health if the compounds are present in recycled water. Some of the compounds of concern include: disinfection by-products (DBP), $N$ - 
nitrosodimethylamines (NDMA), pesticides, herbicides, pharmaceuticals and endocrine disrupting chemicals (EDCs) (Boyd et al., 2003).

\subsection{Typical Processes Used in Wastewater Treatment}

Wastewater collected from municipalities, communities and industries contains a wide range of pollutants. The treatment train normally adopted includes physical, chemical, and biological methods. WWTP is divided into four major treatment groups: i) preliminary, ii) primary, iii) secondary, and iv) tertiary advanced treatment. Conventional sewage treatment includes primary treatment to remove the majority of suspended solids, secondary biological treatment to degrade the biodegradable binding organic matter and nutrients and tertiary treatment to remove a portion of the remaining organic and inorganic solids and pathogenic microorganisms through a filtration step.

The preliminary treatment of wastewater removes coarse and readily settleable inorganic solids with the size range of more than $0.01 \mathrm{~mm}$, such as sand and grit particles. The removal is carried out using screens and grit chambers, respectively. After coarse and floating solids are removed in preliminary treatment, primary treatment removes the bulk of suspended solids through sedimentation tanks or clarifiers. During sedimentation, particles from $0.1 \mathrm{~mm}$ to $35 \mu \mathrm{m}$ including both organic and inorganic matter are removed. Of the 70-90 percent of suspended solid removed by sedimentation, 30-40 percent of this reduction is oxygen-demanding suspended solids (Tchobanoglous and Burton, 1991). 
Secondary treatment is employed to remove oxygen-demanding organic pollutants which are present mostly in the dissolved form. This process utilizes bacterial biological degradation to remove the dissolved pollutants. However, these microbes will produce soluble microbial products and extracellular polymeric substances, which can be toxic and inhibit nitrification.

Tertiary treatment removes part of the remaining organic pollutants through a filtration process. Final disinfection is often utilized to reduce the bacterial count, particularly pathogenic microbes. This is mainly adopted to avoid inferior-treated effluent quality and to protect the receiving water.

\subsection{Wastewater Characteristics}

An understanding of the chemical composition of wastewater is important since this allows an understanding of reactions and interactions with the organic and inorganic compounds (Roila et al., 1994). The organic and biologic composition of wastewater is a reflection of the influent water usage (such as industrial, domestic and agricultural activities). Wastewater is treated, discharged to a receiving stream, and withdrawn for reuse by a downstream population. Consequently, the chemical and bacteriological composition must be monitored to ensure public health.

Concentrations of nutrients, such as nitrogen and phosphorus, should be reduced to a level protective of the receiving stream (e.g., eutrophication and subsequent siltation). Releases of microbiological contaminants and other pollutants should also be 
minimized to protect downstream users. The organic composition of wastewater is approximately 50 percent proteins, 40 percent carbohydrates, 10 percent fats and oils, and trace amounts (e.g. $\mu \mathrm{g} / \mathrm{L}$ or less) of priority pollutants, surfactants, and emerging contaminants. The microbiological composition of domestic wastewater often contains $10^{5}-10^{8}$ colony forming unit (CFU)/mL of coliform organisms, $10^{3}-10^{4} \mathrm{CFU} / \mathrm{mL}$ fecal streptococci, $10^{1}-10^{3}$ protozoan cysts, and $10^{1}-10^{2}$ virus particles. For adequate protection of public health, the safety of wastewater discharged to a receiving stream must be ensured (Ellis, 2004).

Fundamental information on specific characteristics of organic matter is important in the optimization of treatment processes used in WWTP. The chemical composition of the sediments, organic macromolecules, or sewage sludge has been identified in many studies (del Rio et al., 1998; Réveillé et al., 2003; Müller et al., 2000; Her et al., 2002; Leenheer and Croue, 2003).

\subsection{Constituents of EfOM in BTSE}

The presence of trace organic pollutants in wastewater has been the cause of increasing public concern in recent decades due to potential health risks. EfOM in wastewater consists of both particulates and dissolved substances, which has been found to include several trace organic contaminants including EDCs and PPCPs (Halling-Sorensen et al., 1998; Daughton and Ternes, 1999; Snyder et al., 1999; Snyder et al., 2001d; Vanderford et al., 2003). EfOM can be summarized into three general classes based on their origins:

i) natural organic matter (NOM) derived from drinking water sources, 
ii) synthetic organic compounds produced during domestic use and disinfection by-products generated during disinfection processes of water and wastewater treatment and

iii) soluble microbial products derived during biological processes of wastewater treatment (Drewes and Fox, 1999).

The constituents that are found in BTSE are shown in Figure 1. The fraction of particulate organic material measured as suspended solids (SS) includes protozoa, algae, bacterial floc and single cell, microbial waste products and other miscellaneous debris. Dissolved organic matter (smaller than $0.45 \mu \mathrm{m}$ ) are typically cell fragments and macromolecules. Thus, EfOM can be classified into two main groups by size groupings:

i) particulate organic carbon (POC) above $0.45 \mu \mathrm{m}$ and

ii) dissolved organic carbon (DOC) below that limit. Both groups include a wide variety of constituents (Figure 1). 


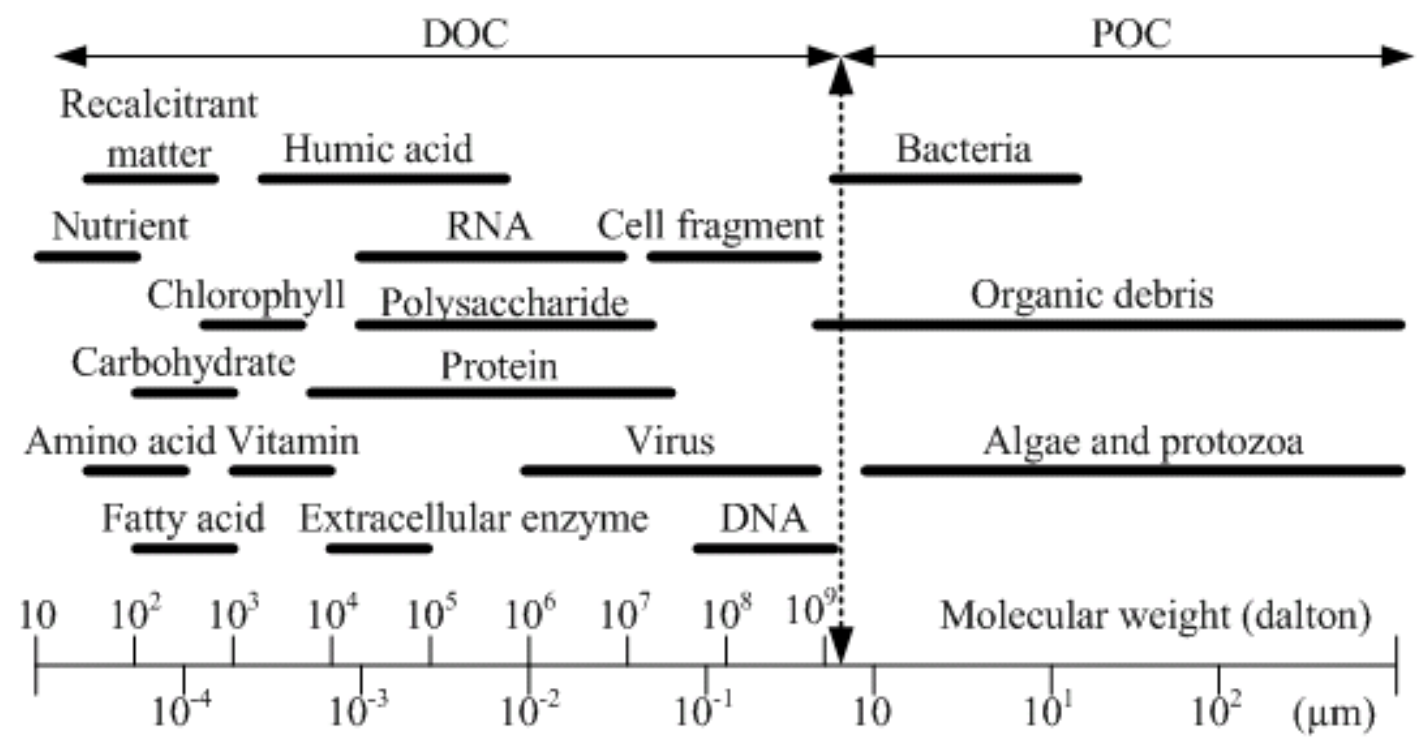

Figure 1 Typical organic constituents in BTSE and their size ranges (adapted from Levine et al., 1985)

Painter (1973) and Levine et al. (1985) showed that organic contaminants of interest in wastewater range in size from less than $0.001 \mu \mathrm{m}$ to well over $100 \mu \mathrm{m}$. The major macromolecules in BTSE are the polysaccharides, proteins, lipids, nucleic acids and NOM (Levine et al., 1985). EfOM in the range from $10^{3}$ to $10^{6}$ daltons include humic acids and fulvic acids present in drinking water. Wastewater compounds smaller than $10^{3}$ daltons include carbohydrates, amino acids, vitamins, and chlorophyll. Persistent chemical compounds such as dichloro-diphenyl-trichloroethane (DDT), polychlorinated biphenyls and other substances of public health are often lower molecular weight (MW) compounds (Stull et al, 1996; Pempkowiak and Obarska-Pempkowiak, 2002). To remove these compounds, it is important to examine the interrelationship between contaminant size ranges and wastewater treatment operations and processes. 
The POC includes zooplankton, algae, bacteria, and debris organic matter from soil and plants. It can easily be removed by solid-liquid separation processes. However, the DOC can pass on many effects on water quality and therefore it remains a focus of research in wastewater treatment (Shon et al., 2005a). Figure 2 shows the most significant DOC components in water in terms of different fractions.

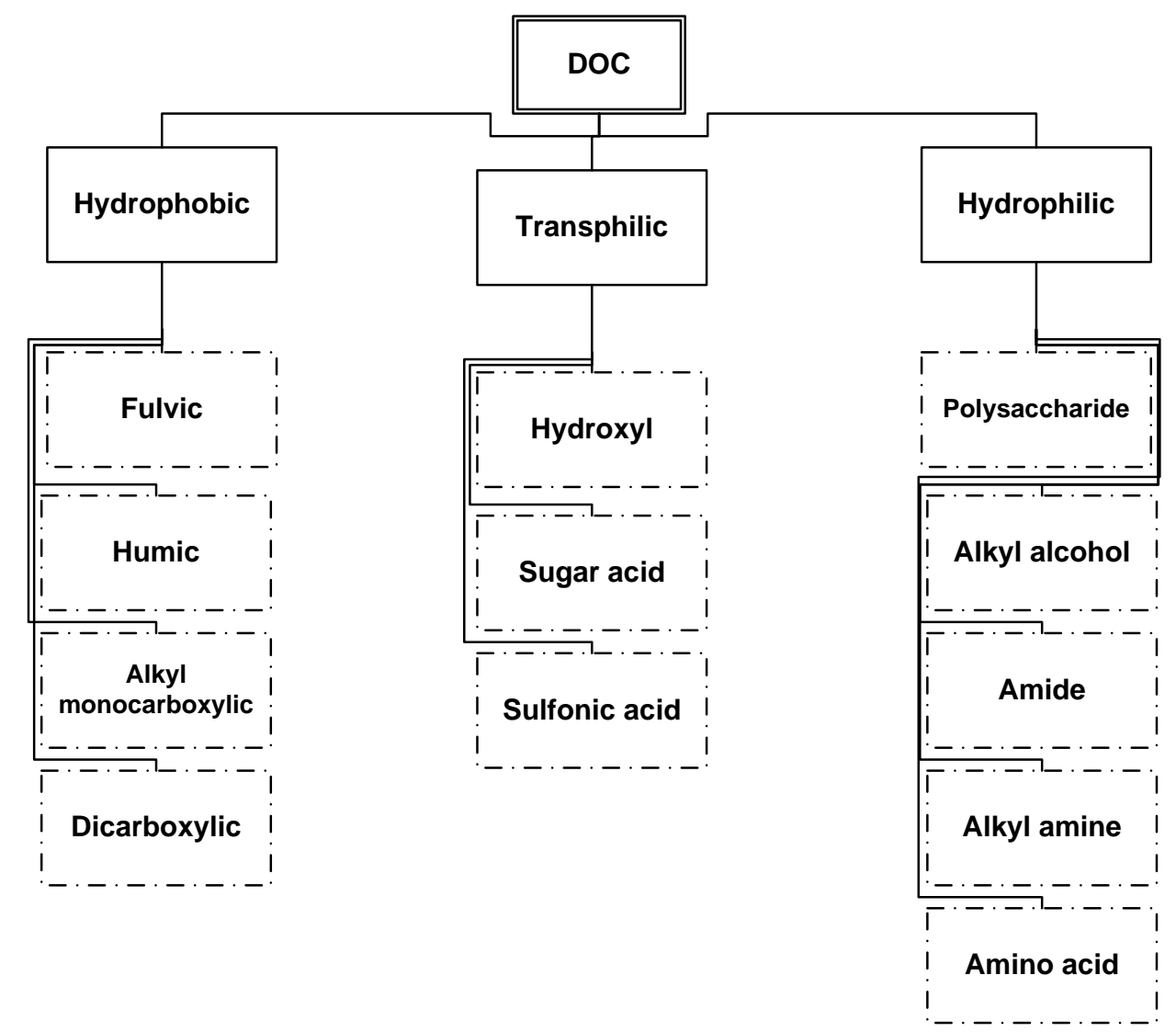

Figure 2 Different fractions of DOC and their constituents (adapted from Thurman, 1985; Cho, 1998) 


\subsection{Adverse and Benign Effects of EfOM}

EfOM affects essentially all chemicals and biological processes in aquatic environments. It has a stabilizing effect, opposite to that of metal ions. EfOM can have the following consequences:

i) precursor for disinfection-by-product formation,

ii) exerts higher coagulant and oxidant demands,

iii) fouls adsorbents and membranes;

iv) causes corrosion problems, and

v) supplies substrate for biomass growth in water distribution networks.

The presence of EfOM in BTSE can also be helpful in some instances. For instance, EfOM substances can bind with metals and organic compounds to reduce bioavailability and subsequent toxicity. Some treatment processes implicitly benefit from the physicochemical effects of EfOM on colloids. Humic acids can be used as direct means to extract pollutants (Yates and Von Wandruszka, 1999).

\subsection{Characteristics of EfOM from BTSE}

Wastewater qualities can be classified into 3 groups: i) physical, ii) chemical and iii) biological. These characteristics, and some influencing factors, are presented in Table 1. It should be noted that many of the parameters listed are interrelated. Tchobanoglous 
and Burton (1991) observed that temperature, a physical property, affects both the biological activity in the wastewater and the amounts of gases dissolved in wastewater.

Table 1 Physical, chemical and biological characteristics of wastewater and their sources (adapted from Tchobanoglous and Burton, 1991)

\begin{tabular}{|c|c|c|}
\hline & Characteristic & Sources \\
\hline \multirow[t]{4}{*}{$\begin{array}{l}\text { Physical } \\
\text { properties }\end{array}$} & Color & $\begin{array}{l}\text { Domestic and industrial wastes, natural decay } \\
\text { of organic materials }\end{array}$ \\
\hline & Odor & Decomposing wastewater, industrial wastes \\
\hline & Solids & $\begin{array}{l}\text { Domestic water supply, domestic and } \\
\text { industrial wastes, soil erosion, } \\
\text { inflow/infiltration }\end{array}$ \\
\hline & Temperature & Domestic and industrial wastes \\
\hline \multirow[t]{11}{*}{$\begin{array}{l}\text { Chemical } \\
\text { properties }\end{array}$} & $\begin{array}{l}\text { Carbohydrates, fats, oils } \\
\text { and grease }\end{array}$ & Domestic, commercial and industrial wastes \\
\hline & Pesticides & Agricultural wastes \\
\hline & Phenols & Industrial wastes \\
\hline & $\begin{array}{l}\text { Proteins, Surfactants } \\
\text { and volatile organic } \\
\text { matter }\end{array}$ & Domestic, commercial, and industrial wastes \\
\hline & Alkalinity and chlorides & $\begin{array}{l}\text { Domestic wastes, domestic water supply, } \\
\text { groundwater, infiltration }\end{array}$ \\
\hline & Heavy metals & Industrial wastes \\
\hline & Nitrogen & Domestic and agricultural wastes \\
\hline & Phosphorus & $\begin{array}{l}\text { Domestic, commercial, and agricultural } \\
\text { wastes; natural runoff }\end{array}$ \\
\hline & Sulfur & $\begin{array}{l}\text { Domestic water supply; } \\
\text { commercial, and industrial wastes }\end{array}$ \\
\hline & $\begin{array}{l}\text { Hydrogen sulfide and } \\
\text { methane }\end{array}$ & Decomposition of domestic wastes \\
\hline & Oxygen & $\begin{array}{l}\text { Domestic water supply, surface-water } \\
\text { infiltration }\end{array}$ \\
\hline \multirow{2}{*}{$\begin{array}{l}\text { Biological } \\
\text { properties }\end{array}$} & Animals and plants & Open watercourses and treatment plants \\
\hline & $\begin{array}{l}\text { Eubacteria } \quad \text { and } \\
\text { archaebacteria } \\
\text { Viruses }\end{array}$ & $\begin{array}{l}\text { Domestic wastes, surface-water infiltration, } \\
\text { treatment plants } \\
\text { Domestic wastes }\end{array}$ \\
\hline
\end{tabular}

Conventional wastewater treatment can not removal all contaminants, as recent discoveries have indicated that trace chemicals in effluents can impact fish at $\mathrm{ng} / \mathrm{L}$ 
concentrations (Bevans et al., 1996; Kramer et al., 1998; Renner, 1998; Jobling et al., 2003; Snyder et al., 2004a; Parrott and Blunt, 2005). Suspended solids can lead to developing sludge deposits and anaerobic conditions when unfiltered wastewater is discharged into an aquatic environment. In addition, their biological stabilization can lead to the depletion of oxygen and to an increase in septic conditions. Nutrients, particularly nitrogen, phosphorus, and carbon, are essential components for bacterial growth. When discharged into the aquatic environment, these nutrients can ultimately lead to the growth of undesirable aquatic life. However, nutrients also essential for a healthy aquatic environment and some level of productivity is required to sustain healthy fish populations. Therefore, complete elimination of nutrients and carbon may have an unhealthy impact on receiving waters, hence careful thought should be given to any water quality changes in effluents discharged to surface water.

\subsection{Specific EfOM Components Present in BTSE}

The contaminants in BTSE can be separated into size fractions based upon successive sedimentation, centrifugation, and filtration. The four molecular size fractions are classified by range as settleable, supracolloidal, colloidal, and soluble. The size range and the organic content of each fraction are summarized in Table 2. An important conclusion from the early studies is that particles smaller than $1.0 \mu \mathrm{m}$ can be degraded biochemically at a much more rapid rate than particles larger than $1.0 \mu \mathrm{m}$ (Levine et al., 1985). 
Table 2 Composition of organic materials in wastewater (adapted from Levine et al., 1985)

\begin{tabular}{|c|c|c|c|c|}
\hline & \multicolumn{4}{|c|}{ Classification } \\
\hline & Soluble & Colloidal & Supracolloidal & Settleable \\
\hline Size range $(\mu \mathrm{m})$ & $<0.08$ & $0.08-1.0$ & $1-100$ & $>100$ \\
\hline COD (\% of total) & 25 & 15 & 26 & 34 \\
\hline TOC (\% of total) & 31 & 14 & 24 & 31 \\
\hline \multicolumn{5}{|c|}{ Organic constituents (\% of total solids) } \\
\hline Grease & 12 & 51 & 24 & 19 \\
\hline Protein & 4 & 25 & 45 & 25 \\
\hline Carbohydrates & 58 & 7 & 11 & 24 \\
\hline $\begin{array}{l}\text { Biochemical } \\
\text { oxidation rate, } \mathrm{k}, \mathrm{d}^{-1} \\
\text { (base } 10 \text { ) }\end{array}$ & 0.39 & 0.22 & 0.09 & 0.08 \\
\hline
\end{tabular}

Most of the EfOM in the treated water is found in the soluble fraction (86\% of the COD). The elimination of EfOM by biological treatment is $90 \%$ for the soluble fraction and 96\% for the bulk EfOM (Dignac et al., 2000).

In a wastewater, about 75 percent of the suspended solids and 40 percent of the filterable solids are organic in nature (Levine et al., 1985). These solids are derived from both animals and plants as well as their activities. Organic compounds are normally comprised of a combination of carbon, hydrogen and oxygen with nitrogen in some cases. Other important elements, such as sulphur, phosphorus and iron, may also be present.

Small quantities of a large number of different synthetic organic molecules include surfactants, organic priority pollutants, volatile organic compounds, and agricultural 
pesticides. The number of such compounds is growing as organic molecules are continually being synthesized. The presence of these substances has complicated wastewater treatment because many of them either cannot be or are slowly decomposed biologically.

Along with protein, carbohydrate, fat, oil, grease and urea, wastewater also contains small quantities of a large number of different synthetic organic molecules. Typical examples include surfactants, priority pollutants, volatile organic compounds, and agricultural pesticides. The number of such compounds is increasing as organic molecules are continually synthesized and introduced into commerce. The presence of these substances has complicated wastewater treatment since several have been found to be resistant to biodegradation (Snyder et al., 2004b).

\subsubsection{Extracellular Polymeric Substances and Soluble Microbial}

\section{Products}

During biological wastewater treatment, biomass not only consumes organic material present in the wastewater, but also produces soluble microbial products and extracellular polymeric substances (Parkin and McCarty, 1981; Namkung and Rittmann, 1986; Noguera et al., 1994; Barker and Stuckey, 2001). These classes of compounds appear to be cellular components that are released during cell lysis, compounds that diffuse through the cell membrane, or compounds that are excreted from some other 
purposes (Rittmann and McCarty, 2001). These cellular products are ubiquitous in biological treatment and constitute the majority of the effluent COD.

Most bacteria produce extracellular polymeric substances that take part in forming microbial aggregates. Bacteria grow in suspended cultures or in biofilms. The microbial biofilm includes bacterial cells enveloped by a matrix of large polymeric molecules. By definition, extracellular polymeric substances are located at or outside the cell surface. Their composition may be controlled by different processes, such as active secretion, shedding of cell surface material, cell lysis and adsorption from the environment (Wingender et al., 1999).

Soluble microbial products can be subdivided into two categories:

i) substrate utilization associated with compounds that are produced directly during substrate metabolism, and;

ii) biomass-associated products that are formed from the biomass, presumably as part of decay (Namkung and Rittmann, 1986).

Toxicity of soluble microbial products is of increasing concern. These products may actually be more toxic than the original organic compounds present in BTSE. Mutagenic response is more in BTSE than in the primary effluent (Rittmann et al., 1987). Some microbial products have been found to inhibit nitrification. More details on these microbial products can be found in Rittmann et al. (1987) and Barker and Stuckey (2001). 


\subsubsection{Protein}

Proteins are the major constituents of animal organisms. Some soluble microbial products also consist of proteins and amino acids. Proteins are complex in chemical structure and unstable, being subject to many forms of decomposition. Some are soluble in BTSE, while others are insoluble. All proteins contain carbon, hydrogen, and oxygen as well as a high and constant proportion of nitrogen (about 16 percent). Urea and proteins are the primary sources of nitrogen in BTSE. Foul odors are produced during protein decomposition (Tchobanoglous and Burton, 1991).

Amino acids and proteins are potential carbon and nitrogen sources for heterotrophic bacteria. Because of their importance to protein synthesis, bacterial metabolism and algal/bacterial interactions, amino acids and proteins have received significant attention. Organic nitrogen results in forming nitrogenous DBPs (Bolto et al., 2004), which is of health and regulatory concern as well as related to membrane fouling (Shon et al., 2005a).

\subsubsection{Carbohydrates}

Carbohydrates include sugars, starches, cellulose and wood fiber, all of which are found in wastewater. Some carbohydrates, notably the sugars, are soluble in water, while others, such as starches, are insoluble. Sugars tend to decompose as the enzymes of certain bacteria and yeasts induce fermentation producing alcohols and carbon dioxide. 
Starches, on the other hand, are more stable but are converted into sugars by microbial activity as well as by dilute mineral acids. From the standpoint of bulk and resistance to decomposition, cellulose is the most important carbohydrate observed in wastewater due to its particular decomposition. Wastewaters containing high levels of carbohydrates are often from industries such as food processing and fermentation (Fontanier et al., 2006). Kumar et al. (1998) and Pawar et al. (1998) discussed the treatment of high level of present in carbohydrate wastewater.

Table 3 shows the distribution of different sugars in influent wastewater and BTSE. The EfOM percentage of monosaccharides follows the order of glucose $>$ mannose $>$ xylose $>$ rhamnose (Dignac et al., 2000).

Table 3 Comparison of the distributions of monosaccharide in the influent wastewater and their efficiencies (adapted from Dignac et al., 2000)

\begin{tabular}{lcc}
\hline Monosaccharides & Total monosaccharide of the influent (\%) & Removal efficiency (\%) \\
\hline Rhamnose & 6 & 80 \\
Fucose & 3 & 50 \\
Ribose & 5 & 83 \\
Arabinose & 26 & 96 \\
Xylose & 42 & 96 \\
Mannose & 3 & 3 \\
Galactose & 7 & 93 \\
Glucose & 8 & 82 \\
\hline
\end{tabular}

Although some polysaccharides such as lignin are difficult to degrade, in general carbohydrates provide a carbon source to micro and macroorganisms. As such, they also have an important role in biological treatment processes. Carbohydrates do not interfere 
significantly with traditional treatment technologies but are recognized as foulants in membrane separation processes (Cho, 1998; Jarusutthirak, 2002; Shon et al., 2005a).

\subsubsection{Fat, Oil and Grease (FOG)}

FOGs are the third most abundant component in BTSE. FOGs occur in domestic wastewater through introduction of materials like butter, lard, margarine and vegetable oils. In addition, some mineral oil can also enter the wastewater treatment plant. FOGs can be measured as fatty acids. Practically, all fatty acids are eliminated during the biological treatment (98\% to $100 \%$ ), except for the $20: 4 \omega 6$, which is removed to a lesser degree (93\%) (Dignac et al., 2003). This fatty acid is not found in bacteria, and more likely originates from non-degraded lipids of the wastewater. The profiles of fatty acids in the influent wastewater and BTSE are not significantly different.

FOGs in wastewater can cause many problems in both sewer pipes and WWTPs. If FOGs are not removed before the discharge of the waste, it can interfere with the ecological of the surface waters and create unsightly appearance due to floating matter and films.

\subsubsection{Surfactants}

The term surfactant is an abbreviation for surface active agent. Surfactants lower the surface tension of a liquid, allowing easier spreading. Generally made of organic 
compounds that consist of both hydrophobic and hydrophilic groups, surfactants are semi-soluble in both organic and aqueous solvents. Thus, they prefer neither to be in water or in an organic phase. They are placed at the boundary between the organic and water phases. In some cases, they will congregate together and form micelles. Ionic detergents include sodium deoxycholate and sodium dodecyl sulfate. Surfactants are important ingrediants on widely used cleaning products used in a diversity of household and industrial applications. Many other household products, such as toothpastes, shampoos, shaving foams and bubble baths, also contribute to surfactants in wastewater influents. Surfactants can be a significant source of pollution and can be transferred to waterways by industrial and domestic effluents.

Prior to 1965, alkylbenzene sulfonates were the most common surfactants in commerce, which created problems since these surfactants resist biodegradation. As a result of legislation, alkylbenzene sulfonates have been replaced by linear alkylsulfonate (LAS), which is biodegradable. Surfactants are widely used despite some risk to the aquatic environment by certain types of detergents and/or metabolic degradants. For instance, certain degradation products from the widely used alkylphenol polyethoxylate surfactants, have been shown to be estrogenic and bioaccumulate (Snyder et al., 2001a; Snyder et al., 2001b). 


\subsubsection{Endocrine disrupting chemicals and pharmaceuticals and personal care products (PPCPs)}

Until the beginning of the 1990s, so called priority pollutants were the main focus of environmental concerns regarding wastewater effluents. The U.S. Environmental Protection Agency has identified approximately 129 priority pollutants even as early as 1981 as persistently harmful compounds to aquatic environment (USEPA, 2006). Most priority pollutants are considered bioaccumulative organic compounds or heavy metals. These compounds are still quite important; however, many have been banned for certain uses (i.e., DDT and lindane), while others have been strictly regulated in order to better protect the environment. However, in recent years the presence of trace concentrations (below $\mu \mathrm{g} / \mathrm{L}$ ) of various compounds in wastewater has become a concern due to their potential to disrupt the endocrine system of animals (Snyder et al., 2005a).

Endocrine disrupting chemicals (EDCs) refer to a class of toxicity in which an endogenous or exogenous chemical has the ability to mimic or block the natural action of endocrine system in animals (USEPA, 1997; Ankley et al., 1998; Gillesby and Zacharewski, 1998). The ability of certain chemicals to mimic estrogen has been known for decades (Cook et al., 1934; Stroud, 1940; Schueler, 1946; Fisher et al., 1952; Welch et al., 1969). However, the discovery that human hormones and a synthetic hormone used as a pharmaceutical for birth control may have been primarily responsible for reproductive impacts in fish below wastewater outfalls stimulated a plethora of new research on EDCs (Harries et al., 1997; Desbrow et al., 1998; Snyder et al., 1999; 
Snyder et al., 2001d; Jobling et al., 2002). In response to amendments to the US Safe Drinking Water Act and Food Quality Protection Act mandating comprehensive screening of commercial chemicals for endocrine activity, the US EPA set forth to develop a screening program to evaluate approximately 87,000 chemicals in commerce for which minimal, if any, data are available regarding endocrine-related toxicity (USEPA, 1997). The endocrine system of animals is vast and affects nearly all aspects of metabolism, growth, development, and reproduction. However, the primary classes of EDCs are compounds which mimic or block the natural action of estrogen, androgen, and/or thyroid.

It is generally accepted that there are three major classes of endocrine endpoints:

i) estrogenic (compounds that mimic or block natural estrogens),

ii) androgenic (compounds that mimic or block natural testosterone) and

iii) thyroidal (compounds with direct or indirect impacts to the thyroid).

Most research has focused only on estrogenic compounds; however, disruption of androgen and thyroid function may be of greater or equal importance biologically. Despite early reports of steroids and pharmaceuticals in US waters (Stumm-Zollinger and Fair, 1965; Tabak and Bunch, 1970; Garrison et al., 1975; Hignite and Azarnoff, 1977; Tabak et al., 1981), the link between the birth control pharmaceutical, ethynyl estadiol, and estrogenic effects in fish below wastewater outfalls has stimulated a flurry of new research seeking to identify and quantify other pharmaceuticals (HallingSorensen et al., 1998; Daughton and Ternes 1999; Snyder et al., 2001c; Kolpin et al., 
2002). Personal care products represent another group of emerging contaminants that can also be detected at ng/L concentrations in wastewater. Collectively, pharmaceuticals and personal care products are known as PPCPs. Most of the EDCs and PPCPs are more polar than traditional contaminants and the majority have acidic or basic functional groups. These properties, coupled with occurrence at trace levels (i.e. < $1 \mu \mathrm{g} / \mathrm{L}$ ) create unique challenges for both analytical detection and removal processes (Snyder et al., 2003a). Molecular structures of several EDC and PPCP compounds can be found in Vanderford et al. (2003). Details of removal of EDC and PPCP compounds in WWTP can be found elsewhere (Tabak et al., 1981; Alcock et al., 1999; Ternes et al., 1999a; Ternes et al., 1999b; Drewes et al., 2002; Lindqvist et al., 2005; Snyder et al., 2005b)

Daughton and Ternes (1999) reviewed the occurrence of over 50 individual PPCPs from more than 10 broad classes of therapeutic agents or personal care products in environmental samples. Acidic drugs are one major group of PPCPs which have been frequently detected in WWTP effluents. Among the acidic pharmaceuticals, bezafibrate, naproxen, and ibuprofen occur most frequently at concentrations as high as $4.6 \mu \mathrm{g} / \mathrm{L}$ in a municipal WWTP (Daughton and Ternes, 1999). Tixier et al. (2003) found that carbamezapine was the most abundant pharmaceutical in a WWTP effluent discharging into Lake Greifensee (Switzerland), followed by diclofenac and naproxen. Their elimination during their passage through WWTP was usually found to be quite low in the range 35-90\%. 
As the use of synthetic compounds in household and industry increase and as analytical instrumentation becomes increasingly more sensitive, many more chemicals will be detectable in WWTP effluents. Table 4 presents general classes of emerging contaminants. The majority of these contaminants are not currently regulated; however, they may be candidates for future regulation once environmental and human health relevance has been established. An interesting characteristic of these contaminants is that they need not persist in the environment to cause negative effects, since their high transformation/removal rates can be compensated for by their continuous introduction into environment (Barceló, 2003). For most of these emerging contaminants, occurrence, risk assessment, and ecotoxicological data are not yet available and it is therefore difficult to predict their actual risk. 
Table 4 Classes of emerging compounds (adapted from Barceló, 2003)

\begin{tabular}{|c|c|}
\hline Compound class & Examples \\
\hline & Pharmaceuticals \\
\hline $\begin{array}{l}\text { Veterinary and human } \\
\text { antibiotics }\end{array}$ & Trimethoprim, erythromycin \\
\hline Analgesics and anti- & Codein, ibuprofen, acetaminophen, acetylsalicylic \\
\hline inflammatory drugs & acid, diclofenac, fenoprofen \\
\hline Psychiatric drug & Diazepam \\
\hline Lipid regulators & Bezafibrate, clofibric acid, fenofibric acid \\
\hline B-blockers & Metoprolol, propranolol, timolol \\
\hline X-ray contrast media & Lopromide, iopamidol, diatrizoate \\
\hline $\begin{array}{l}\text { Steroids and hormones } \\
\text { (contraceptives) }\end{array}$ & Estradiol, estrone, estriol, diethylstilbestrol \\
\hline & Personal care products \\
\hline Fragrances & Nitro-, polycyclic-, and macrocyclic- musks \\
\hline Sun-screen agents & Benzophenone, methylbenzylidene camphor \\
\hline Insect repellents & N,N-dimethyltoluamide (DEET) \\
\hline Antiseptics & Triclosan, chlorophene \\
\hline $\begin{array}{l}\text { Surfactants and surfactant } \\
\text { metabolites }\end{array}$ & $\begin{array}{l}\text { Alkylphenol ethoxylates, alkylphenols (nonylphenol } \\
\text { and octylphenol), alkylphenol carboxylates }\end{array}$ \\
\hline Flame retardants & $\begin{array}{l}\text { Polybrominated diphenyl ethers (PBDEs), Tetrabromo } \\
\text { bisphenol A, Tris(2-chloroethyl)phosphate (TCEP) }\end{array}$ \\
\hline $\begin{array}{l}\text { Industrial additives and } \\
\text { agents }\end{array}$ & Chelating agents (EDTA), aromatic sulfonates \\
\hline Gasoline additives & Dialkyl ethers, methyl-4-butyl ether (MTBE) \\
\hline Disinfection by-products & $\begin{array}{l}\text { Iodo-THMs, bromoacids, bromoacetonitriles, } \\
\text { bromoaldehydes, cyanoformaldehyde, bromate, } \\
\text { NDMA }\end{array}$ \\
\hline
\end{tabular}

\section{Overview on Treatment of EfOM}

Treatment processes for limiting EfOM were initially developed in response to the concerns for human and environmental health and the adverse conditions caused by the discharge of organic matter. From about 1900 to the early 1970s, treatment objectives were only concerned with i) the removal of suspended and floating material and ii) the elimination of pathogenic organisms (Tchobanoglous and Burton, 1991). However, as the use of various chemicals has increased, the pollutant component of EfOM has 
become of great interest, especially with recent developments in EDC and PPCP research. Most current WWTPs are not designed to treat these types of substances and a high portion of emerging compounds and their metabolites may escape elimination in WWTP and enter the aquatic environment via effluents (Figure 3).

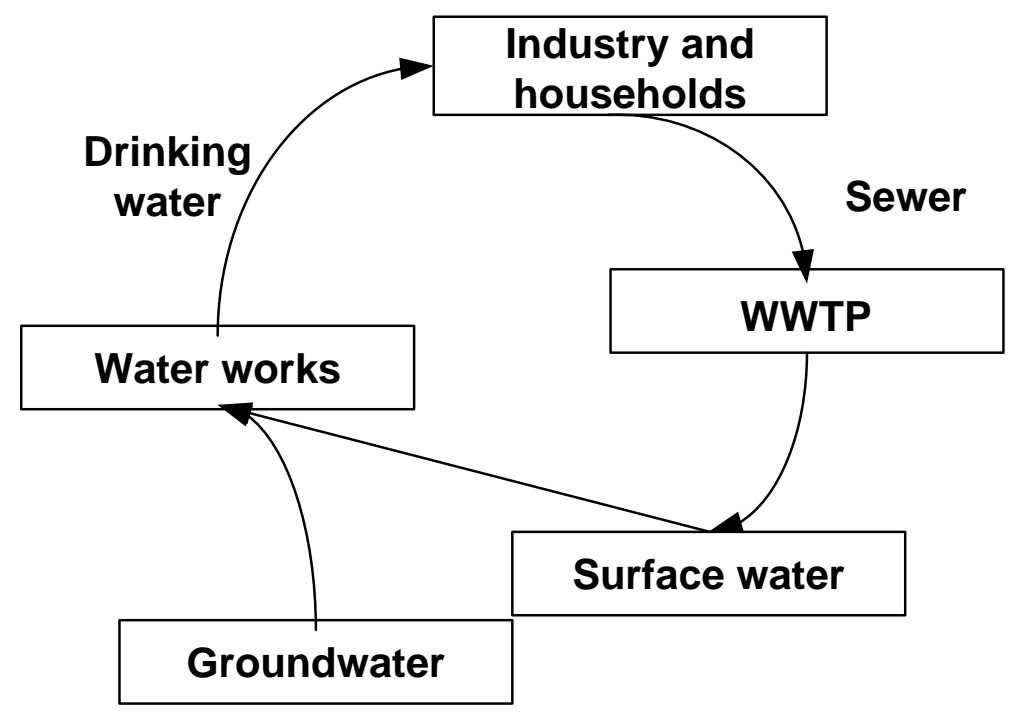

Figure 3 Components of a closed water cycle with indirect potable reuse (adapted from Petrović et al., 2003)

In sewage treatment process EfOM in BTSE is reduced by physical, chemical, and biological means. Treatment methods where the application of physical force predominates are known as physical unit operations. Physical treatments include screening, sedimentation and filtration. Chemical treatment involves the removal or conversion of contaminants by the addition of chemicals or by indirect chemical reactions. Flocculation, adsorption, ion exchange (IX), and disinfection are the most common chemical treatment methods. Biological treatment using microbes to biodegrade organic matter is important to select an appropriate treatment to remove 
specific compounds found in EfOM. In order to remove these compounds, it is necessary to understand the roles and mechanisms of different treatment processes.

In this review, treatment processes such as flocculation, adsorption, biofiltration, ion exchange, advanced oxidation process and membrane processes are considered. The efficiency of different treatment processes is evaluated in terms of TOC/DOC removal, EDC/PPCP removal, and MW distribution since:

i) TOC is a surrogate for general organic contaminant removal by treatments used,

ii) EDCs and PPCPs represent removal of the small MW compounds (about 150 - 500 Daltons) which cannot be completely removed using a conventional treatment process and

iii) MW distribution provides specific removal of different organic sizes.

\subsection{Treatment Process of EfOM}

The effectiveness of specific processes in treating EfOM is strongly influenced by the size (or MW) and structure of EfOM. The size ranges of EfOM removed by different treatment methods are shown in Figure 4. 


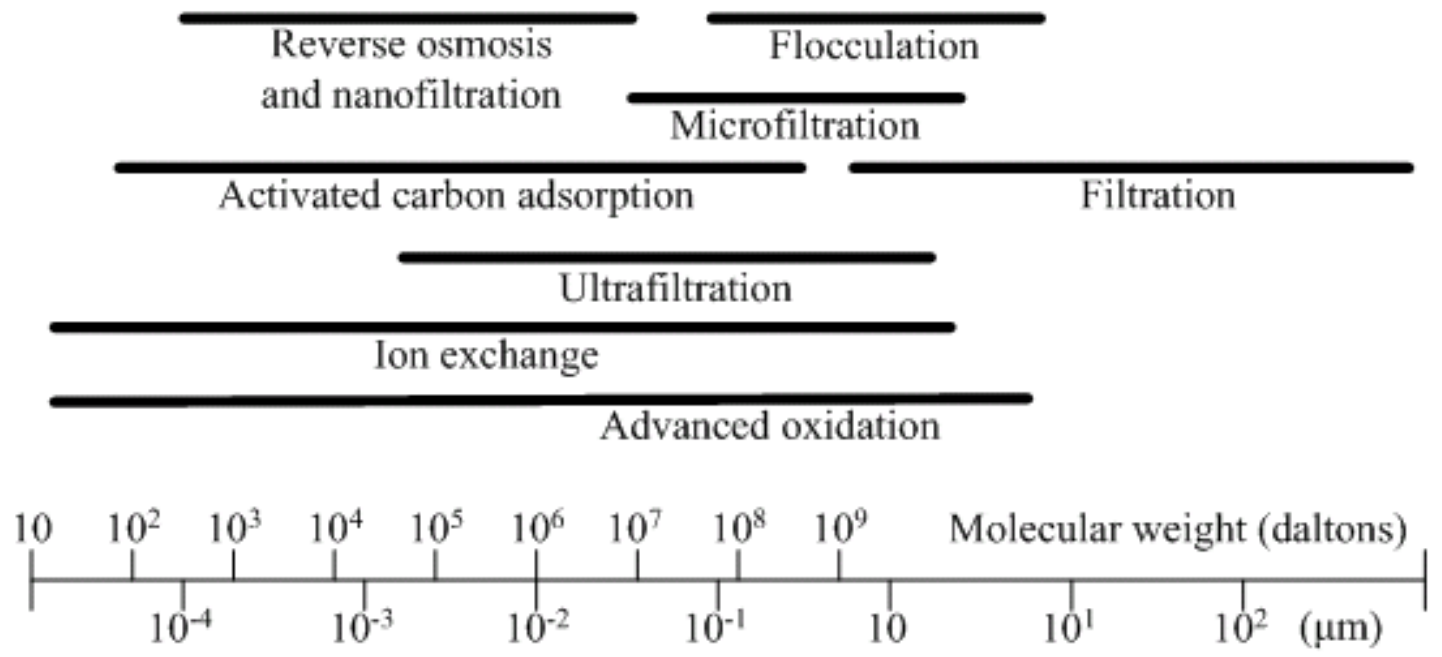

Figure 4 Size ranges of the applied treatments in treating EfOM

\subsubsection{Flocculation}

Since about 1970, the need to provide more complete removal of the organic compounds and nutrients (nitrogen and phosphorus) has prompted interest in chemical flocculation (Tchobanoglous and Burton, 1991). Most colloids in wastewater carry a negative charge, but a colloidal dispersion does not have a net electrical charge. The primary charges on the particles are counterbalanced by charges in the aqueous phase, resulting in an electrical double layer at every interface between the solid and water. The forces of diffusion and electrostatic attraction spread the charge around each particle in a diffuse layer. Repulsive electrical forces and attractive van der Waals forces interact between the particles in the solution, producing a potential barrier that prevents aggregation. The process of overcoming the repulsive barrier and allowing aggregation to occur is called coagulation (DeWolfe et al., 2003). 
Coagulation consists of four distinct mechanisms: i) compression of the diffuse layer (van der Waals interaction), ii) adsorption to produce charge neutralization (destabilization), iii) enmeshment in a precipitate (sweep coagulation) and iv) adsorption to permit interparticle bridging (complex between particle and polymer with synthetic organic coagulant) (Vigneswaran and Visvanathan, 1995). Rapid mixing leads to the charge neutralization of colloids/particles through uniform and immediate disposal of chemicals with water. Flocculation which follows the rapid mixing results in the aggregation of particles. Flocculation can occur through three major mechanisms: i) Brownian movement of fluid molecules (perikinetic flocculation), ii) velocity gradient in the fluid (orthokinetic flocculation) and iii) differential settling of different sizes of particles in the water (Vigneswaran and Visvanathan, 1995).

Coagulants are classified into three main groups in actual practice: i) aluminum sulfate (72\%), ii) iron salts (23\%), and iii) polyaluminum chloride (5\%) (DeWolfe et al., 2003). Alum and ferric chloride are the most common coagulants. The use of ferric chloride and polyaluminum chloride has increased over the last few decades.

\subsubsection{Removal of EfOM by Flocculation}

It is possible to obtain a clear effluent, substantially free from suspended and colloidal solids by flocculation. $\mathrm{FeCl}_{3}$ flocculation can remove 80 to $90 \%$ of the total suspended solids, 40 to $70 \%$ of $\mathrm{BOD}, 30$ to $60 \%$ of $\mathrm{COD}$, and 80 to $90 \%$ of the bacteria 
(Tchobanoglous and Burton, 1991). However, dissolved organic matter removal depends on the characteristics of BTSE (Table 5).

Table 5 EfOM removal by flocculation

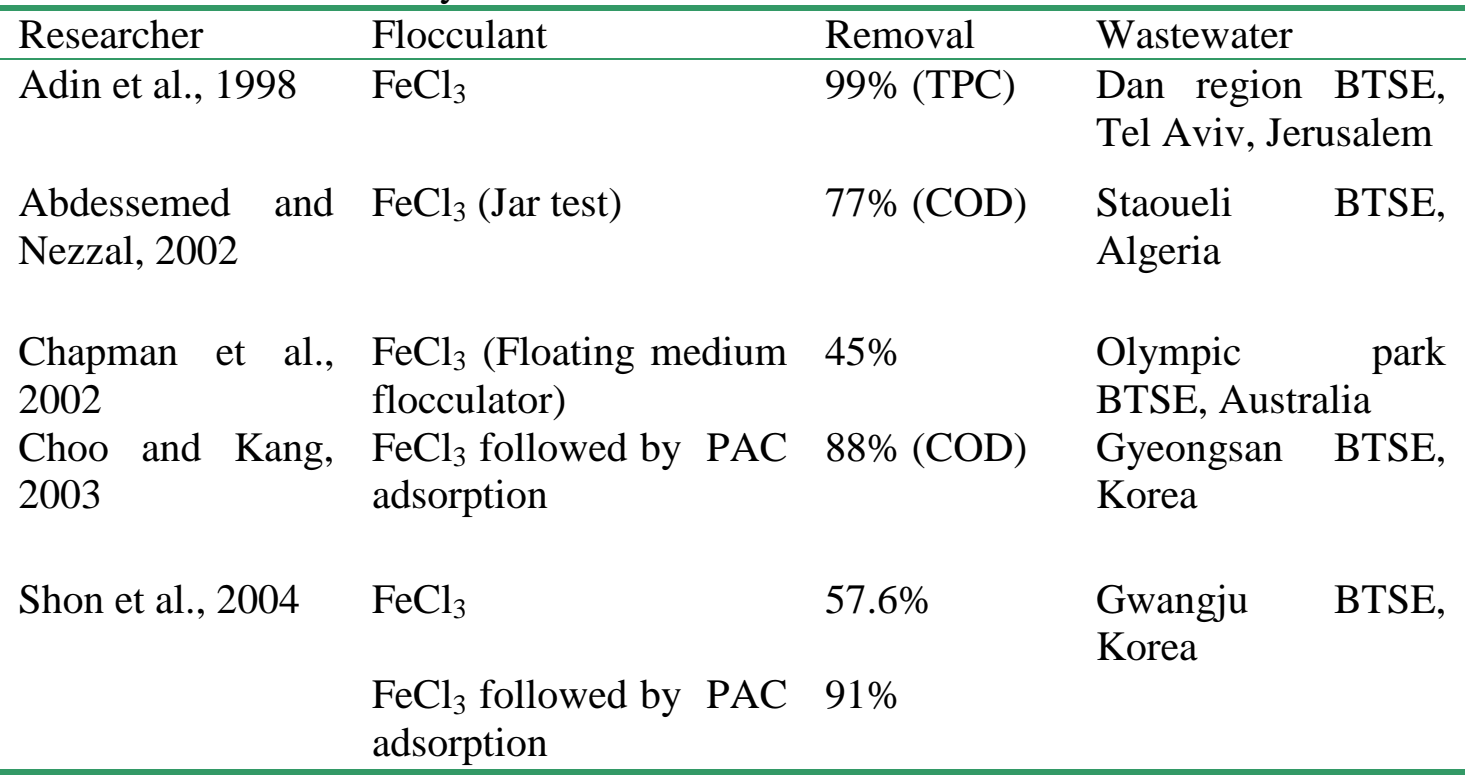

Table 6 presents the removal of EDC and PPCP by flocculation (Westerhoff et al., 2005). The concentrations of ferric chloride and alum used in this study were $30 \mathrm{mg} / \mathrm{L}$ and $28 \mathrm{mg} / \mathrm{L}$. The water was stirred at $100 \mathrm{rpm}$ for $2 \mathrm{~min}$ and at $30 \mathrm{rpm}$ for $20 \mathrm{~min}$. Then, it was settled for $1 \mathrm{hr}$. The compounds which consist of aromatic ring such as benzo[a]pyrene, benzo[g,h,l]perylene, benzo[k]fluoranthene, mirex, benzo[b]fluranthene, and benzo[a]anthracene showed a high removal of more than $85 \%$. However, the compounds such as diazepam, diclofenac, and meprobamate, indicated the lowest removal (less than 10\%). Alum as a coagulant resulted in a slightly better removal compared to ferric chloride coagulants. EDCs or PPCPs are removed by partially adsorbing on particles in water and metal hydroxide particles formed during flocculation (Westerhoff et al., 2005). 
Table 6 Removal efficiency (\%) of EDC and PPCP with different flocculants (adapted from Westerhoff et al., 2005)

\begin{tabular}{lcclcc}
\hline EDC/PPCP & $\begin{array}{c}\text { Ferric } \\
\text { chloride }\end{array}$ & Alum & EDC/PPCP & $\begin{array}{c}\text { Ferric } \\
\text { chloride }\end{array}$ & Alum \\
\hline Acetaminophen & 0 & 0 & a-BHC & 5 & 16 \\
Androstenedione & 0 & 17 & Acenephthene & 0 & 7 \\
Atrazine & 0 & 0 & Acenapththylene & 0 & 11 \\
Caffeine & 0 & 3 & a-Chlordane & 28 & 30 \\
Carbamzepine & 0 & 7 & Aldrin & 50 & 51 \\
DEET & 0 & 6 & Anthracene & 0 & 0 \\
Diazepam & 0 & 5 & b-BHC & 12 & 27 \\
Diclofenac & 0 & 0 & Benz[a]anthracene & 26 & 29 \\
Dilantin & 0 & 0 & Benzo[a]pyrene & 66 & 67 \\
Erythromycin-H2O & 0 & 2 & Benzo[b]fluoranthene & 59 & 61 \\
Estrodiol & 0 & 12 & Benzo[k]fluoranthene & 62 & 64 \\
Estriol & 0 & 4 & Chrysene & 28 & 32 \\
Estrons & 0 & 9 & d-BHC & 8 & 22 \\
Ethynylestradiol & 0 & 16 & DDD & 24 & 26 \\
Fluoxetine & 0 & 20 & DDE & 57 & 57 \\
Genfibrozil & 2 & 20 & DDT & 45 & 46 \\
Hydrocodone & 0 & 6 & Diedrin & 3 & 0 \\
Ibuprofen & 0 & 0 & Endrin & 0 & 0 \\
Iopromide & 0 & 12 & Fluoranthene & 3 & 12 \\
Meprobamate & 0 & 0 & Fluorene & 3 & 8 \\
Naproxen & 0 & 0 & Galaxolide & 15 & 18 \\
Oxybenzone & 0 & 0 & g-BHC & 5 & 22 \\
Pentoxifylline & 0 & 2 & g-Chlordane & 38 & 37 \\
Progesterone-APCI & 0 & 20 & Heptachlor & 30 & 30 \\
Progesterone-ESI & 0 & 6 & Heptachlor epoxide & 7 & 13 \\
Sulfamethoxazole & 0 & 0 & Methoxychlor & 29 & 32 \\
TCEP & 0 & 0 & Metolachlor & 9 & 26 \\
Testocterone & 16 & Mirex & 62 & 65 \\
Triclosan & 13 & Musk keton & 0 & 18 \\
Trimethoprim & 3 & Naphtalene & 20 & 29 \\
Phenanthrene & 0 & & & \\
\hline
\end{tabular}


Flocculation can remove moderate amounts of organic contaminants that have a strong affinity for adsorbed EfOM. Most of these compounds are relatively polar (log $\mathrm{K}_{\mathrm{ow}}$ values less than 3) and as a result, only a few EDC and PPCP are removed during this treatment. Adams et al., (2002) also demonstrated that flocculation with alum and iron salts or excess lime/soda ash did not result in significant removal of antibiotics (i.e., carbadox, sulfachlorpyridazine, sulfadimethoxine, sulfamerazine, sulfamethazine,

sulfathiazole, and trimethoprim). Sacher et al., (2000) found that ferric chloride flocculation did not remove several pharmaceuticals (diclofenac, carbamazepine, bezafibrate, and clofibric acid). Certain pesticides were poorly removed by flocculation and approximately $50 \%$ of the PAHs, pyrene, fluoranthene, and anthracene were removed through hydrophobic interactions (Rebhun et al., 1998). In summary, EDCs and PPCPs that are associated with colloidal or particulate material are removed by flocculation followed by sedimentation or filtration.

\subsubsection{Adsorption}

Adsorption is the process of collecting soluble substances that are in solution on a suitable interface. Adsorption is a physical and surface phenomenon by which molecules of organics (adsorbates) are attracted to the surface of adsorbent by intermolecular forces of attraction. Physical adsorption is mainly caused by van der Waals forces and electrostatic forces between adsorbate and adsorbent molecules. In principle, any porous solid can be an adsorbent; however, for an efficient and 
economical adsorption process, the adsorbent must have large surface area, long life, and a well-defined microcrystalline structure.

The main factors that affect the adsorption of EfOM are:

i) the characteristics of adsorbent: surface area, particle size, and pore structure,

ii) the characteristics of adsorbate: solubility, molecular structure, ionic or neutral nature and

iii) the characteristics of the solution: $\mathrm{pH}$, temperature, presence of competing organic and inorganic substances.

Other factors affecting adsorption of organics are related to specific chemical affinities between functional groups on the adsorbate and on the adsorbent. In general, compounds that are not effectively removed are highly soluble (hydrophilic). In the case of organic acids and bases, adsorption is strongly dependent on $\mathrm{pH}$ because of the preference for removal of neutral species from aqueous solution.

\subsubsection{Removal of EfOM by Adsorption}

Previous studies have shown that activated carbon can adsorb EfOM in significant quantities and produce high quality effluent (Summers and Roberts, 1984; Najm et al., 1990). Since BTSE contains different types of organic and inorganic substances, it is possible that physical and chemical adsorption takes place when it comes in contact 
with activated carbon. However, for simplicity reasons, only physical adsorption is considered since most of the adsorption-separations are due to physical adsorption.

The adsorption process is competitive, with the extent of competition depending upon the strength of adsorption of the competing molecules, the concentration of these molecules and the characteristics of the adsorbent. In competitive adsorption, desorption of a compound may take place by displacement by other compounds, as the adsorption process is reversible (Summer and Roberts, 1984). It results in an effluent concentration of EfOM greater than the influent concentration in some cases.

Table 7 presents the removal of EDCs and PPCPs by adsorption. Compared to flocculation, adsorption removes EDCs/PPCPs in significant quantities (Westerhoff et al., 2005). PAC which has the hydrophobic characteristics interacts with nonpolar organic compounds of EDC/PPCP. Snyder et al. (2003a) suggested that PAC adsorption is effective in removing nonylphenol, nonylphenol ethoxylates, triclosan, dilatin, bisphenol A, and octylphenol (about 60 - 80\% removal). 
Table 7 Removal of EDC and PPCP from BTSE by PAC adsorption (adapted from Snyder et al., 2006; Westerhoff et al., 2005)

\begin{tabular}{lclclc}
\hline EDC/PPCP & $\begin{array}{c}\text { Removal } \\
(\%)\end{array}$ & EDC/PPCP & $\begin{array}{c}\text { Removal } \\
(\%)\end{array}$ & EDC/PPCP & $\begin{array}{c}\text { Removal } \\
(\%)\end{array}$ \\
\hline Acetaminophen & 87 & a-BHC & 0 & Fluorene & 96 \\
Androstenedione & 58 & Acenephthene & 90 & Galaxolide & 63 \\
Atrazine & 54 & Acenapththylene & 95 & g-BHC & 67 \\
Caffeine & 19 & a-Chlordane & 82 & g-Chlordane & 0 \\
Carbamzepine & 55 & Aldrin & 92 & Heptachlor & 88 \\
DEET & 0 & Anthracene & 77 & Heptachlor epoxide & 35 \\
Diazepam & 53 & b-BHC & 77 & Methoxychlor & 0 \\
Diclofenac & 64 & Benz[a]anthracene & 91 & Metolachlor & 57 \\
Dilantin & 0 & Benzo[a]pyrene & 94 & Mirex & 90 \\
Erythromycin- & 44 & Benzo[b]fluoranthene & 90 & Musk keton & 73 \\
H2O & & & & & 96 \\
Estrodiol & 2 & Benzo[k]fluoranthene & 91 & Naphtalene & 96 \\
Estriol & 54 & Chrysene & 93 & Phenanthrene & 94 \\
Estrons & 79 & d-BHC & 23 & Meprobamate & 0 \\
Ethynylestradiol & 67 & DDD & 52 & Naproxen & 87 \\
Fluoxetine & 92 & DDE & 93 & Oxybenzone & 93 \\
Genfibrozil & 0 & DDT & 80 & Pentoxifylline & 65 \\
Hydrocodone & 72 & Diedrin & 52 & Progesterone-APCI & 45 \\
Ibuprofen & 48 & Endrin & 14 & Progesterone-ESI & 91 \\
Iopromide & 33 & Fluoranthene & 91 & Sulfamethoxazole & 43 \\
Testocterone & 35 & Trimethoprim & 40 & TCEP & 71 \\
Triclosan & 93 & Pyrene & 85 & & \\
\hline
\end{tabular}

\subsubsection{Biofiltration}

Any type of filter with attached membrane biomass on the filter-media is called a biofilter. It can be a trickling filter used in a wastewater treatment plant, a horizontal rock filter used in a polluted stream, granular activated carbon (GAC) and/or slow sand filter used in a water treatment plant. 
Biofilter has been successfully used to treat organic pollutants from air, water and wastewater. The biofilter (in the form of trickling filter) was first introduced in England in 1893 (Metcalf and Eddy, 1991), and since then, it has been successfully used for the treatment of domestic and industrial wastewater. Originally, this biofilter was developed using rock or slag as filter media, however at present, several types and shapes of plastic media are used. There are a number of small package treatment systems with different brand names that are currently available in the market where different shaped plastic materials are packed as filter media.

In a biofiltration system, the pollutants are removed by biological degradation rather than physical straining as is the case in a normal filter. With the progression of the filtration process, microorganisms (aerobic, anaerobic and facultative bacteria; fungi; algae; and protozoa) are gradually developed on the surface of the filter media and form a biological film or slime layer known as biofilm. The development of biofilm may take few days or months depending on the influent organic concentration. The crucial point for the successful operation of a biofilter is to control and maintain a healthy biomass on the surface of the filter. Since the performance of the biofilter entirely depends on the microbial activities, a constant source of substrates (organic substance and nutrients) is required for its consistent and effective operation. There are three main biological processes that can occur in a biofilter: i) attachment of microorganism, ii) growth of microorganism and iii) decay and detachment of microorganisms. As the success of a biofilter depends on the growth and maintenance of microorganisms (biomass) on the surface of filter media, it is necessary to understand the mechanisms of attachment, growth and detachment on the surface of the filter media (Chaudhary, 2003). 
The parameters that can affect the performance of a biofilter are the characteristics of filter media, hydraulic and organic loading rate, and filter backwash techniques. Other factors that can influence the performance of a biofilter are temperature and the presence of oxidants (e.g., $\mathrm{O}_{3}, \mathrm{H}_{2} \mathrm{O}_{2}, \mathrm{Cl}_{2}$, and $\mathrm{NH}_{4} \mathrm{Cl}$ in the influent) (Urfer et al., 1997, Goel et al., 1995). These factors should be carefully studied when designing a biofiltration system. Typical design values of biofilter for water and wastewater treatment are presented in Table 8.

Table 8 Typical biofilter design parameters used in tertiary wastewater and surface water treatment (adopted from Rachwal et al., 1996)

\begin{tabular}{lccc}
\hline Parameter & $\begin{array}{c}\text { Slow sand } \\
\text { filter }\end{array}$ & $\begin{array}{c}\text { Sand or multi- } \\
\text { media Rapid filter }\end{array}$ & $\begin{array}{c}\text { Granular activated } \\
\text { carbon Rapid filter }\end{array}$ \\
\hline Filtration rate $(\mathrm{m} / \mathrm{h})$ & $0.1-0.3$ & $5-30$ & $5-15$ \\
Media effective size $(\mathrm{mm})$ & $0.2-0.4$ & $0.5-2$ & $0.5-1$ \\
Media depth $(\mathrm{m})$ & $0.3-1.5$ & $0.6-2.5$ & $0.6-3.5$ \\
Media contact time $(\mathrm{h})$ & $1-15$ & $0.07-0.2$ & $0.1-0.5$ \\
Specific Media surface area $\left(\mathrm{m}^{2} / \mathrm{m}^{3}\right)$ & $10,000^{*}$ & $4400^{*}$ & $4600^{*}, 5 \times 10^{8 \#}$ \\
\hline * based on assumed spherical media, \# based on manufacturers quoted molecular scale \\
adsorption surface area
\end{tabular}

\subsubsection{Removal of EfOM by Biofiltration}

A biofilter can be employed either as a primary treatment unit or as secondary unit in the wastewater treatment system or as tertiary filter. In advanced wastewater treatment, biofilter can be used along with conventional physico-chemical processes such as coagulation-flocculation, filtration and sedimentation. The conventional filter and the 
biofilter unit can be combined depending on the suspended solid concentration. Since the main purpose of the biofilter is to remove the dissolved organics, the suspended particles are often removed by a conventional filter before the biofiltration system.

Adsorption of organics and biological degradation of the organic matter adsorbed onto the activated carbon are two major mechanisms for the consistent removal of organics in the GAC biofiltration system. A summary of past research on DOC and EDC/PPCP removal by biofiltration is presented in Tables 9 and 10 .

Table 9 Lists of the DOC removal by filtration with BTSE

\begin{tabular}{llcl}
\hline Researcher & Process & Removal & Wastewater \\
\hline Kim et al., 2002 & - Dual media + GAC biofilter & $64 \%$ & BTSE, \\
& $\begin{array}{l}\text { - Dual media + GAC biofilter } \\
\text { with a flocculant }\end{array}$ & $75 \%$ & Singapore \\
Shon et al., 2003 & $\begin{array}{l}\text { - GAC biofilter } \\
\end{array}$ & $60 \%$ & $\begin{array}{l}\text { Gwangju BTSE, } \\
\text { Korea }\end{array}$ \\
\hline
\end{tabular}


Table 10 Removal of EDC and PPCP with full scale GAC biofilter (ng/L) (Snyder et al., 2006)

\begin{tabular}{llllll}
\hline Compounds & $\begin{array}{l}\text { Raw } \\
\text { water }\end{array}$ & $\begin{array}{l}\text { After } \\
\text { coagulation }\end{array}$ & $\begin{array}{l}\text { GAC } \\
\text { influent }\end{array}$ & $\begin{array}{l}\text { GAC } \\
\text { effluent }\end{array}$ & $\begin{array}{l}\text { GAC } \\
\text { Removal (\%) }\end{array}$ \\
\hline Caffeine & 7.1 & 2.7 & 17 & 3.1 & 81.8 \\
Erythromycin- & 1.4 & 1.9 & 1.8 & $<1.0$ & $<44.4$ \\
$\mathrm{H}_{2} \mathrm{O}$ & & & & & \\
Sulfamethoxazole & 1.2 & 1.6 & 6.0 & $<1.0$ & 83.3 \\
Meprobamate & 2.0 & 2.0 & 1.2 & $<1.0$ & $<16.7$ \\
Dilantin & 1.4 & 2.2 & 1.8 & $<1.0$ & $<44.4$ \\
TCEP & 2.0 & 1.7 & 2.0 & 1.3 & 35 \\
Carbamazepine & 2.5 & 2.4 & 2.2 & $<1.0$ & $<54.5$ \\
DEET & 4.0 & 3.6 & 1.8 & $<1.0$ & $<44.4$ \\
Atrazine & 571 & 571 & 650 & 6.1 & 99.1 \\
Iopromide & 2.2 & 2.4 & 3.3 & $<1.0$ & $<69.7$ \\
Ibuprfen & 2.4 & 2.9 & 1.1 & $<1.0$ & $<9.1$ \\
Gemfibrozil & 4.8 & 4.5 & 1.2 & $<1.0$ & $<16.7$ \\
Metolachlor & 122 & 121 & 122 & $<1.0$ & $<99.2$ \\
\hline
\end{tabular}

\subsubsection{Ion Exchange}

Wastewaters containing low MW EfOM are difficult to treat by coagulation/flocculatioin processes. Ion exchange (IX) is often more economical than activated carbon, carbonaceous resins, or metal oxides in removing EfOM if on-site regeneration of ion exchanger can be performed. The charged impurities in water and wastewater can be easily removed by IX. Since EfOM has a negative charge at neutral $\mathrm{pH}$, basic anion exchange resins are used in wastewater applications (Brattebo et al., 1987). The typical IX application can be divided into two groups: i) strongly basic anion exchange and ii) weakly basic anion exchange.

The quaternary ammonium resins are generally used as strongly basic anion exchange in the chloride form. The following reaction occurs with charged DOC (which is represented by $\mathrm{R}^{-}$and anion exchange resins): 
Resin- $-\mathrm{NMe}_{3}{ }^{+} \mathrm{Cl}^{-}+\mathrm{R}^{-} \leftrightarrow$ Resin- $-\mathrm{NMe}_{3}{ }^{+} \mathrm{R}^{-}+\mathrm{Cl}^{-}$

IX resins used in treating EfOM can be regenerated with an excess of brine or caustic. The generation of a strongly basic resin requires salt and alkali well in excess of the stoichiometric amounts. On the other hand, weakly basic resins require lower amounts of chemicals. The chemicals used in latter case are often lime and mineral acid at only slightly above equivalent levels. The following equation is:

Resin- $\mathrm{NHMe}_{2}{ }^{+} \mathrm{R}^{-}+\mathrm{OH}^{-} \rightarrow$ Resin- $-\mathrm{NMe}_{2}+\mathrm{R}^{-}+\mathrm{H}_{2} \mathrm{O}$

Resin- $\mathrm{NMe}_{2}+\mathrm{H}^{+}+\mathrm{Cl}^{-} \rightarrow$ Resin- $-\mathrm{NHMe}_{2}{ }^{+} \mathrm{Cl}^{-}$

Thus, weakly basic resins have cost advantages in terms of regeneration. The calcium salts of humic and fulvic acids are obtained in the regenerated liquid. Regeneration can be achieved without salt, which can simplify the disposal of the waste (Bolto et al., 2004). The properties of resins that are used in the removal of EfOM are listed in Table 11. 
Table 11 Characteristics of resins used in the treatment of BTSE

\begin{tabular}{|c|c|}
\hline Researcher & Remarks \\
\hline $\begin{array}{l}\text { Brattebo et } \\
\text { al., (1987) }\end{array}$ & $\begin{array}{l}\text { - Strongly basic resins in the chloride form remove EfOM better than their } \\
\text { hydroxide forms. }\end{array}$ \\
\hline $\begin{array}{l}\text { Meyers } \\
(1995)\end{array}$ & - Resins with a smaller particle size are more efficient. \\
\hline $\begin{array}{l}\text { Symons et } \\
\text { al., (1995) } \\
\text { and } \\
\text { Gottlieb, } \\
\text { (1996) }\end{array}$ & $\begin{array}{l}\text { - Better EfOM removal with an IX of polyacrylic skeleton than styrenic } \\
\text { resin. } \\
\text { - More flexible acrylic skeleton enables resins to adsorb more water and } \\
\text { swell, making them less prone to fouling. } \\
\text { - The acrylic skeleton facilitates the removal of HL organic acids in } \\
\text { addition to more abundant HP acids (humics). } \\
\text { - Macroporous resins with a moderate to high porosity are more suited to } \\
\text { stresses in a continuous process compared to gel resins. } \\
\text { - Macroporous resins are more physically stable than gel resins under } \\
\text { aggressive conditions including hydraulic pressures and presence of } \\
\text { chlorine. }\end{array}$ \\
\hline $\begin{array}{l}\text { Frederick, } \\
(1997)\end{array}$ & $\begin{array}{l}\text { - The smaller average particle diffusion distances within the smaller resin } \\
\text { beads result in an improvement to regeneration (and loading) kinetics. } \\
\text { - The same property also results in reductions of rinse times required to } \\
\text { remove regenerant from the beads. }\end{array}$ \\
\hline
\end{tabular}

In water and wastewater applications, magnetic ion exchange resin $\left(\mathrm{MIEX}^{\circledR}\right)$ is increasingly being used (Wert et al., 2005). The MIEX ${ }^{\circledR}$ resin was originally developed in Australia (Orica Watercare Ltd.) for the removal of DOC. The DOC removal from water minimizes the formation of DBP in drinking water supplies. The name MIEX ${ }^{\circledR}$ comes from magnetic ion exchange, because the adsorption is achieved by means of IX and the resin particles contain a magnetized component within their structures (Figure 5). MIEX $^{\circledR}$ has been developed to enable the adsorption of DOC. This process occurs in a stirred contactor, similar to a flash mixer in a conventional water treatment plant. The negatively charged DOC is removed by exchanging with a chloride ion on active sites on the resin surface. 


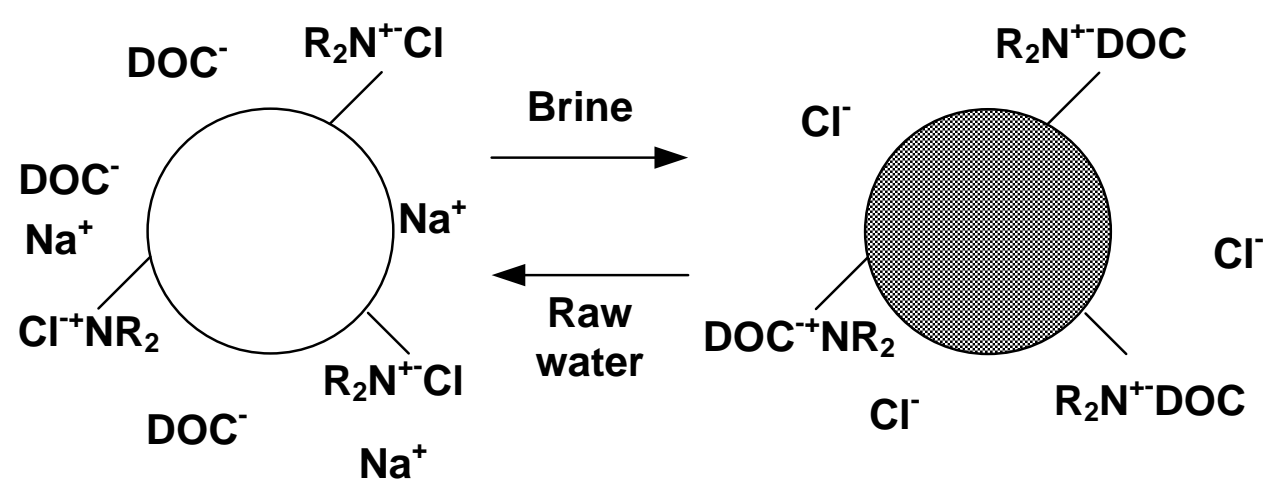

Figure 5 DOC removal mechanisms by MIEX $^{\circledR}$ resin (adapted from Bourke et al., 1999)

Several bench-scale and pilot-scale studies have proved its capability in removing negatively charged EfOM (Bourke et al., 1999). Preliminary experiments indicate that MIEX $^{\circledR}$ and enhanced coagulation can effectively remove small MW organic matter and large MW organic matter, respectively. The process was developed on the following recognized premises (Fearing et al., 2004)

i) resins with quaternary ammonia functional groups are more effective,

ii) resins with a polyacrylic skeleton are the best for EfOM removal,

iii) macroporous resins are more suited to continuous processes than gel resins,

iv) resins need a high specific IX capacity and

v) smaller sized resin particles are more efficient.

\subsubsection{Removal of EfOM by MIEX ${ }^{\circledR}$ Process}


EfOM can be significantly reduced using MIEX $^{\circledR}$. On average, $70-80 \%$ of the EfOM are weak organic acids that are found in ionized form in the $\mathrm{pH}$ range of 6 to 8 . These polydispersed anions have a carboxyl content of 11 to $15 \mathrm{meq} / \mathrm{g}$ TOC which improves removal by IX (Symons et al., 1995).

In terms of MW of organic matter, smaller EfOM (MW 1000-10000 daltons) are exchanged rapidly both during resin loading and regeneration. On the other hand, large EfOM (MW > 10000 daltons) have been found to have slower exchange kinetics but form stronger ionic bonds with the resin (Zhang et al., 2005). As a result of this, they are harder to extract during resin regeneration and have potential to foul the resin. The smallest EfOM (MW < 1000) is neutral, and thus not removed by resin. In addition, the effectiveness of EfOM removal by IX varies from one source water to another depending not only on the composition of EfOM but also on $\mathrm{pH}$, temperature and presence of other anions, especially sulphate. Efficiency of the EfOM removal in an IX process can be improved by optimizing resin characteristics and/or process conditions. Both of above factors have been utilized in the MIEX ${ }^{\circledR}$ DOC process (Slunjski et al., 1999).

A pilot plant study treating raw water received from a water treatment plant revealed the following: MIEX ${ }^{\circledR}$ resin reduced the raw water THM formation potential (THMFP) by 69.5\% (from $167 \mathrm{~g} / \mathrm{L}$ to $51 \mathrm{~g} / \mathrm{L}$ ) and the HAA formation potential (HAAFP) by 61\% (from $94 \mathrm{~g} / \mathrm{L}$ to $37 \mathrm{~g} / \mathrm{L}$ ) (Hammann, 2004). MIEX ${ }^{\circledR}$ treatment reduced the raw water DOC by an average of $71 \%$ (from $11.8 \mathrm{mg} / \mathrm{L}$ to $3.4 \mathrm{mg} / \mathrm{L}$ ), which subsequently reduces DBP formation. Table 12 presents the removal of EDC and PPCP by MIEX ${ }^{\circledR}$ treatment. 
Some EDCs/PPCPs (triclosan and diclofenac are effectively removed, while most EDCs/PPCPs cannot be removed by this treatment. The DOC removal by $\mathrm{MIEX}^{\circledR}$ was 60 to $70 \%$ in BTSE. Zhang et al. (2005) reported that MIEX ${ }^{\circledR}$ resin can easily be regenerated and even after several regenerations with a similar removal with Gwangju BTSE, Korea.

Table 12 Percent removal of EDC and PPCP by different concentrations of MIEX ${ }^{\circledR}$ (adapted from Snyder et al., 2004c)

\begin{tabular}{lcccc}
\hline \multicolumn{1}{c}{ EDC/PPCP } & (5 mL of MIEX)/(L of water) & $10 \mathrm{~mL} / \mathrm{L}$ & $15 \mathrm{~mL} / \mathrm{L}$ & $20 \mathrm{~mL} / \mathrm{L}$ \\
\hline Triclosan & 84 & 90 & 93 & 94 \\
Sulfamethoxazole & 0 & 0 & 0 & 4 \\
Oxybenzone & 4 & 24 & 36 & 40 \\
Naproxen & 18 & 20 & 44 & 53 \\
Ibuprofen & 0 & 2 & 16 & 20 \\
Gemfibrozil & 0 & 0 & 13 & 20 \\
Ethynylestradiol & 0 & 0 & 20 & 20 \\
Estradiol & 0 & 0 & 3 & 3 \\
Dilantin & 0 & 0 & 21 & 22 \\
Diclofenac & 68 & 81 & 88 & 90 \\
\hline
\end{tabular}

\subsubsection{Advanced Oxidation Process (AOP)}

AOP is typically characterized by the generation of the highly reactive hydroxyl radical $(\cdot \mathrm{OH})$ that can mineralize dissolved organic pollutants into $\mathrm{CO}_{2}$ and $\mathrm{H}_{2} \mathrm{O}$. They are: i) ozonolysis, ii) UV/ozone, iii) $\mathrm{UV} / \mathrm{H}_{2} \mathrm{O}_{2}$ iv) irradiation with electrons and v) combinations of the above methods. This process has shown considerable potential in the treatment of a number of recalcitrant organic pollutants such as humic substances, EDC, PPCP, textile dye waste and sewage sludge. In addition, this process has been 
tested with alternative disinfectants to disinfect protozoa such as Cryptosporidium (Clancy and Hargy 2004). In the recent years, this technique has also been coupled with membrane systems to obtain better results (Molinari et al., 2001; Tang and Chen, 2001).

Oxidative hydroxyl radical (HO•) can be generated by photochemical pathways (Table 13). The oxidative potential of species indicates the power of an oxidant, with a higher value indicating higher reactivity. For example, the oxidative potential for $\mathrm{OH} \bullet$ is +2.8 volts, compared to ozone at 2.07 volts. The hydroxyl radical is a strong and non-specific oxidant and therefore able to rapidly oxidize a large diversity of organic molecules. Many of the AOPs utilize the chemical hydrogen peroxide as a source of hydroxyl radicals. The oxidizing strength of hydrogen peroxide alone is relatively weak (oxidative potential +1.76 volts), but the addition of UV light enhances the rate and strength of oxidation through production of increased amounts of hydroxyl radicals. Hydrogen peroxide (even in low concentrations) will enhance other AOPs, as the molecule easily splits into two hydroxyl radicals. Fenton's reagent has been proven to be very effective in the treatment of organic molecules. However, this process is costly and forms complicated sludge that requires disposal.

Photocatalytic oxidation is relatively a new technology that can be used to mineralize the refractory EfOM. During the past 10 years, there has been considerable research and commercial interest in the use of AOP for the treatment of organic contaminants in wastewater. 
Table 13 Advanced oxidation processes used in water treatment

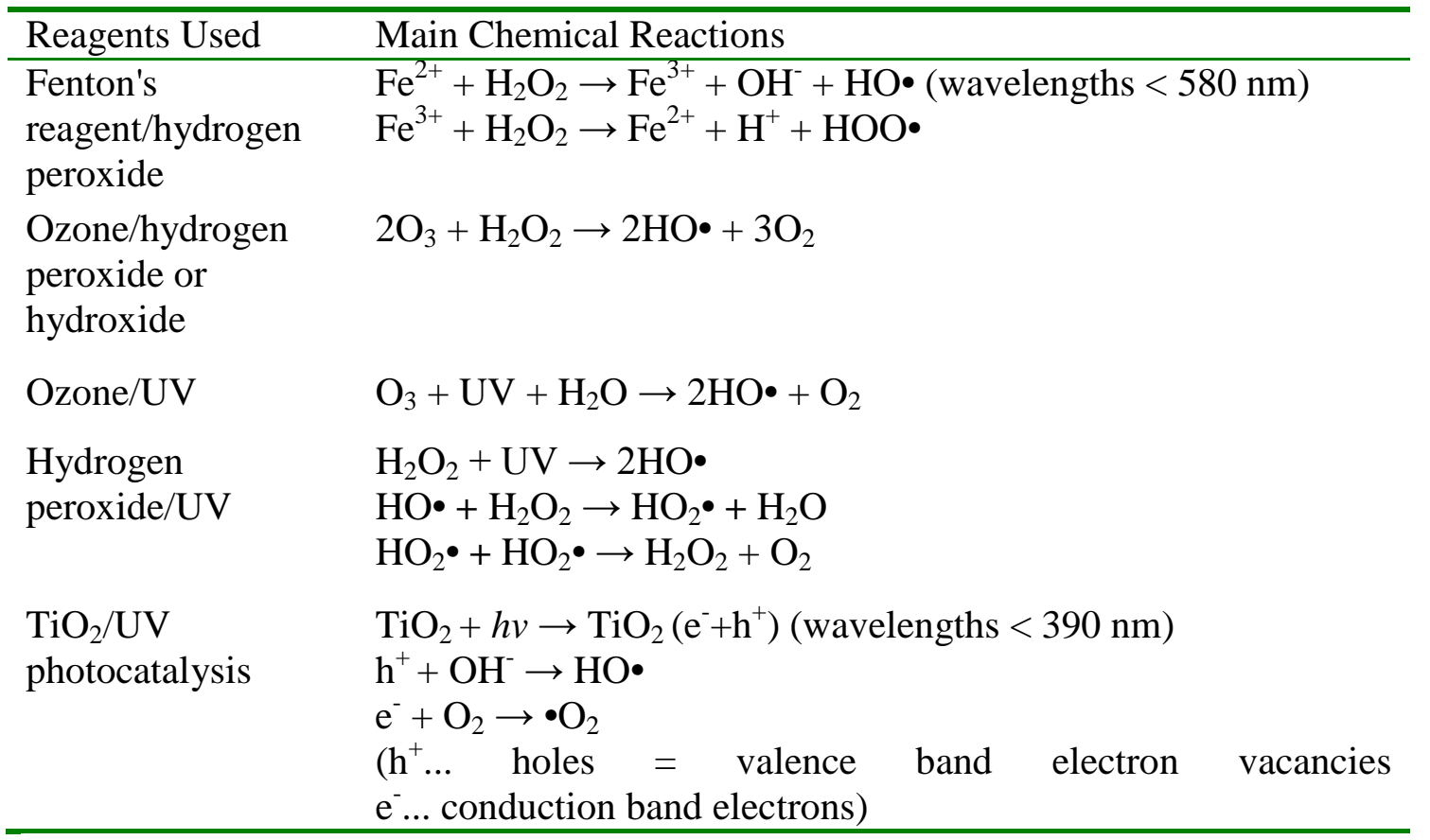

The $\mathrm{TiO}_{2} / \mathrm{UV}$ photocatalytic process is also one of the attractive AOPs as its reactive species is the $\mathrm{HO}$ radical as in all other AOPs. Degradation of waste compound proceeds via oxidative (electrophilic) attack of $\mathrm{HO} \bullet$ and leads to mineralization to yield innocuous $\mathrm{CO}_{2}$ and mineral acids, taking advantage of the extremely high redox potential of the HO•. Photoinduced electrons $\left(\mathrm{e}^{-}\right)$and positive holes $\left(\mathrm{h}^{+}\right)$are produced from $\mathrm{TiO}_{2}$ with UV light. These charged species can further generate free radicals. The highly oxidizing positive hole $\left(\mathrm{h}^{+}\right)$is considered to be the dominant oxidizing species contributing to the mineralization process resulting from the $\mathrm{TiO}_{2}$ photocatalysis (Chu and Wong, 2004). The principal advantages of the $\mathrm{TiO}_{2} /$ UV process compared to other AOPs are:

i) suitable in wastewater treatment without the addition of large amounts of chemicals, ii) no follow-up treatments (e.g., filtration) are necessary and 
iii) applicability over a wide range of $\mathrm{pH}$ values.

There are also some limitations of UV/oxidation (Gogate and Pandit, 2004).

(i) The aqueous stream being treated must allow good transmission of UV light (high turbidity causes interference on the passage of UV light). Free radical scavengers can inhibit contaminant destruction efficiency. Excessive dosages of chemical oxidizers may act as a scavenger.

(ii) The aqueous stream to be treated by UV/oxidation should be relatively free of heavy metal ions (less than $10 \mathrm{mg} / \mathrm{L}$ ) and insoluble oil or grease to minimize the potential of fouling of the quartz sleeves.

(iii) When $\mathrm{UV} / \mathrm{O}_{3}$ is used on volatile organics, the contaminants may be volatilized (e.g., stripped) rather than getting destroyed. They would then have to be removed from the off-gas by activated carbon adsorption or catalytic oxidation.

(iv) Costs may be higher than competing technologies because of energy requirements. Pretreatment of the aqueous stream may be required to minimize ongoing cleaning and maintenance of UV reactor and quartz sleeves.

(v) Handling and storage of oxidizers require special safety precautions.

\subsubsection{Removal of EfOM by AOPs}

Typical AOPs use ozone, hydrogen peroxide and UV radiation to generate the hydroxyl radicals in treating EfOM in BTSE. One of the more recent and more practical methods of producing hydroxyl radicals is the use of UV along with a suspended $\mathrm{TiO}_{2}$ catalyst. 
This method is believed to have the advantage of better control in terms of producing the hydroxyl radicals while avoiding or minimizing the formation of the potentially toxic DBP (Al-Bastaki, 2003).

Table 14 presents removal of EfOM from BTSE by different AOPs. The use of $\mathrm{O}_{3} / \mathrm{H}_{2} \mathrm{O}_{2} / \mathrm{UV}$ results in a shorter reaction time and requires less oxidant than the other AOPs (Ito et al., 1998). When photocatalysis is combined with $\mathrm{FeCl}_{3}$, the removal of DOC increases by up to $90 \%$. This may be due to the decrease of organic loading and/or increase of Fenton reaction (Shon et al., 2005b).

Table 14 Comparison of DOC removal with different AOP in BTSE

\begin{tabular}{|c|c|c|c|}
\hline Researcher & Condition & Processes & $\begin{array}{l}\text { DOC } \\
\text { Removal } \\
(\%)\end{array}$ \\
\hline \multirow{3}{*}{$\begin{array}{l}\text { Ito et al., } 1998 \\
\text { (Hiroshima } \\
\text { BTSE, Japan) }\end{array}$} & \multirow{3}{*}{$\begin{array}{l}\mathrm{O}_{3} \text { dosage: } 2.86 \mathrm{mg} \mathrm{O}_{3} \mathrm{~min}^{-1} \text {, } \\
\mathrm{H}_{2} \mathrm{O}_{2} \text { : less than } 200 \mathrm{mg} / \mathrm{L}, \mathrm{UV} \\
\text { intensity }(253 . .7 \mathrm{~nm}): 2.6^{*} 10^{-6} \\
\text { Einstein s}^{-1} \text {, air: } 100 \mathrm{~mL} / \mathrm{min}\end{array}$} & $\mathrm{O}_{3} / \mathrm{H}_{2} \mathrm{O}_{2} / \mathrm{UV}$ & 55 \\
\hline & & $\mathrm{O}_{3} / \mathrm{H}_{2} \mathrm{O}_{2}$ & 20 \\
\hline & & $\mathrm{H}_{2} \mathrm{O}_{2} / \mathrm{UV}$ & 45 \\
\hline Shon et al., & EfOM initial concentration $=6.65$ & $\mathrm{TiO}_{2} / \mathrm{UV}$ & 50 \\
\hline $2005 b$ & $\mathrm{mg} / \mathrm{L} ; \mathrm{TiO}_{2}$ concentration $=2 \mathrm{~g} / \mathrm{L}$; & $\mathrm{O}_{3} / \mathrm{TiO}_{2} / \mathrm{UV}$ & 75 \\
\hline (Gwangju & air $=25 \mathrm{~L} / \mathrm{min}, \quad P A C=1 \mathrm{~g} / \mathrm{L}$, & $\mathrm{H}_{2} \mathrm{O}_{2} / \mathrm{TiO}_{2} / \mathrm{UV}$ & 80 \\
\hline \multirow[t]{2}{*}{ BTSE, Korea) } & $\mathrm{FeCl}_{3}=1 \mathrm{mM}, \mathrm{H}_{2} \mathrm{O}_{2}=1 \mathrm{mM}, \mathrm{O}_{3}$ & $\mathrm{FeCl}_{3} / \mathrm{TiO}_{2} / \mathrm{UV}$ & 90 \\
\hline & $=0.1 \mathrm{~L} / \mathrm{min}$ & $\mathrm{PAC} / \mathrm{TiO}_{2} / \mathrm{UV}$ & 80 \\
\hline
\end{tabular}

Practically any organic contaminants that are reactive with the hydroxyl radical can potentially be treated. A wide variety of organic and explosive contaminants are susceptible to destruction by UV/oxidation, including petroleum hydrocarbons; chlorinated hydrocarbons that are used as industrial solvents and cleaners. In many cases, chlorinated hydrocarbons that are resistant to biodegradation may be effectively 
treated by UV/oxidation. Typically, easily oxidized organic compounds, such as those with double bonds (e.g., trichloroethylene and vinyl chloride), as well as simple aromatic compounds (e.g., toluene, benzene, xylene, and phenol), are rapidly destroyed in UV/oxidation processes (Table 15). More details can be found elsewhere (Gogate and Pandit, 2004; Pirkanniemi and Silanpää, 2002).

Table 15 Easily oxidized organic compounds by photocatalytic processes (adapted from Pirkanniemi and Sillanpää, 2002)

\begin{tabular}{|c|c|c|c|}
\hline & Compounds & Catalyst & $\begin{array}{l}\text { Spectral range and } \\
\text { oxidant }\end{array}$ \\
\hline \multirow[t]{2}{*}{ Chlorinated } & 4-chlorophenol & $-\mathrm{TiO}_{2}$ on $\mathrm{SiO}_{2}$ & $\mathrm{UV}$ and $\mathrm{H}_{2} \mathrm{O}_{2}$ \\
\hline & & $\begin{array}{l}\text { - Pt- } \mathrm{TiO}_{2} \text { on } \\
\text { ambersorb }\end{array}$ & UV \\
\hline organics and & dichloroethene, (and & & \\
\hline phenolic & $\begin{array}{l}\text { toluene, ethylbenzene, } \\
\text { xylene), }\end{array}$ & & \\
\hline \multirow[t]{4}{*}{ compounds } & 2,4-Dichlorophenol & $\begin{array}{l}\text { - Fenton on Nafion } \\
\text { membrane }\end{array}$ & $\begin{array}{l}\text { Visible light and } \\
\mathrm{H}_{2} \mathrm{O}_{2}\end{array}$ \\
\hline & Pentachlorophenol & - $\mathrm{TiO}_{2}$ (sol-gel) & UV \\
\hline & 4-Chlorophenol & $\begin{array}{l}\text { - } \mathrm{TiO}_{2} \text { on silica } \\
\text { fiber glass }\end{array}$ & UV \\
\hline & $\begin{array}{l}\text { Phenol and ortho- } \\
\text { substituted phenolic } \\
\text { compounds: 2- } \\
\text { chlorophenol, guaiacol, } \\
\text { catecol }\end{array}$ & $-\mathrm{TiO}_{2}$ & UV \\
\hline \multirow[t]{5}{*}{ Others } & formic acid & $-\mathrm{TiO}_{2}$ & UV and sonolysis \\
\hline & Nitrotoluenes & $-\mathrm{TiO}_{2}$ & $\mathrm{UV}$ and $\mathrm{O}_{2}$ \\
\hline & Formic acid & - Fe on $\mathrm{TiO}_{2}$ & UV \\
\hline & Benzamide & - $\mathrm{TiO}_{2}$ on fiberglass & UV \\
\hline & Dithiocarbamate & - $\mathrm{TiO}_{2}$ on fiberglass & UV \\
\hline
\end{tabular}

Tables 16 and 17 present the removal of EDC/PPCP by different AOPs. The processes between conventional oxidation (chlorination) and AOP (ozone and ozone- $\mathrm{H}_{2} \mathrm{O}_{2}$ ) are compared in terms of individual removal. Chlorination removes the phenolic 
compounds such as $17 \beta$-estradiol, oxybenzone and triclosan by up to $90 \%$, whereas the removal of the ketone compounds such as androstenedione, progesterone and testostrone is less than $40 \%$. The reactive site of each molecule is predictable using chlorination. A single aromatic bond is broken from double bond by chlorination. The removal of DOC by ozonation in general is better than that of chlorination (Snyder et al., 2003a).

Table 16 Removal of EDC and PPCP with chlorination at pH 5.5 (adapted from Westerhoff et al., 2005)

\begin{tabular}{lclclc}
\hline EDC/PPCP & $\begin{array}{c}\text { Removal } \\
(\%)\end{array}$ & EDC/PPCP & $\begin{array}{c}\text { Removal } \\
(\%)\end{array}$ & EDC/PPCP & $\begin{array}{l}\text { Removal } \\
(\%)\end{array}$ \\
\hline Acetaminophen & 96 & a-BHC & 26 & g-BHC & 21 \\
Androstenedione & 40 & Acenephthene & 92 & g-Chlordane & 30 \\
Atrazine & 15 & Acenapththylene & 92 & Heptachlor & 39 \\
Caffeine & 58 & a-Chlordane & 28 & Heptachlor epoxide & 21 \\
Carbamzepine & 98 & Aldrin & 50 & Methoxychlor & 43 \\
DEET & 16 & Anthracene & 91 & Metolachlor & 32 \\
Diazepam & 71 & b-BHC & 16 & Mirex & 8 \\
Diclofenac & 96 & Benz[a]anthracene & 91 & Musk keton & 25 \\
Dilantin & 32 & Benzo[a]pyrene & 71 & Naphtalene & 46 \\
Erythromycin-H2O & 95 & Benzo[b]fluoranthene & 71 & Phenanthrene & 68 \\
Estrodiol & 98 & Benzo[k]fluoranthene & 86 & Oxybenzone & 96 \\
Estriol & 98 & Chrysene & 89 & Pentoxifylline & 86 \\
Estrons & 98 & d-BHC & 21 & Progesterone-APCI & 50 \\
Ethynylestradiol & 98 & DDD & 24 & Progesterone-ESI & 50 \\
Fluoxetine & 20 & DDE & 34 & Sulfamethoxazole & 97 \\
Gemfibrozil & 98 & DDT & 25 & TCEP & 4 \\
Hydrocodone & 98 & Diedrin & 28 & Testocterone & 52 \\
Ibuprofen & 44 & Endrin & 22 & Triclosan & 97 \\
Iopromide & 7 & Fluoranthene & 94 & Trimethoprim & 98 \\
Meprobamate & 16 & Fluorene & 30 & Pyrene & 53 \\
Naproxen & 93 & Galaxolide & 39 & & \\
\hline & & & & &
\end{tabular}


Table 17 Removal of EDC and PPCP with ozone $/ \mathrm{H}_{2} \mathrm{O}_{2}$ (adapted from Snyder et al., 2005b)

\begin{tabular}{lclclc}
\hline EDC/PPCP & $\begin{array}{c}\text { Removal } \\
(\%)\end{array}$ & EDC/PPCP & $\begin{array}{c}\text { Removal } \\
(\%)\end{array}$ & $\begin{array}{l}\text { EDC/PPCP } \\
\text { Removal } \\
(\%)\end{array}$ \\
\hline Acetaminophen & 96 & a-BHC & 16 & g-BHC & 13 \\
Androstenedione & 98 & Acenephthene & 89 & g-Chlordane & 0 \\
Atrazine & 52 & Acenapththylene & 92 & Heptachlor & 54 \\
Caffeine & 98 & a-Chlordane & 0 & Heptachlor epoxide & 8 \\
Carbamzepine & 98 & Aldrin & 50 & Methoxychlor & 91 \\
DEET & 83 & Anthracene & 91 & Metolachlor & 86 \\
Diazepam & 85 & b-BHC & 0 & Mirex & 23 \\
Diclofenac & 96 & Benz[a]anthracene & 88 & Musk keton & 33 \\
Dilantin & 88 & Benzo[a]pyrene & 71 & Naphtalene & 88 \\
Erythromycin-H2O & 96 & Benzo[b]fluoranthene & 89 & Phenanthrene & 94 \\
Estrodiol & 98 & Benzo[k]fluoranthene & 87 & Pyrene & 93 \\
Estriol & 98 & Chrysene & 92 & Oxybenzone & 96 \\
Estrons & 98 & d-BHC & 9 & Pentoxifylline & 98 \\
Ethynylestradiol & 98 & DDD & 75 & Progesterone-APCI & 98 \\
Fluoxetine & 98 & DDE & 62 & Progesterone-ESI & 98 \\
Gemfibrozil & 98 & DDT & 61 & Sulfamethoxazole & 97 \\
Hydrocodone & 98 & Diedrin & 0 & TCEP & 15 \\
Ibuprofen & 88 & Endrin & 93 & Testocterone & 98 \\
Iopromide & 60 & Fluoranthene & 93 & Triclosan & 82 \\
Meprobamate & 61 & Fluorene & 93 & Trimethoprim & 98 \\
Naproxen & 93 & Galaxolide & 89 & & \\
\hline & & & & &
\end{tabular}

\subsubsection{Membrane Technology}

Membrane technology has been found to be a successful technology in wastewater reuse. Microfiltration (MF) and ultrafiltration (UF) membrane systems have already proven their advantages in terms of superior water quality. Nanofiltration (NF) and reverse osmosis (RO) membranes have been used in wastewater reclamation (Shon et al., 2005a). NF membranes can reject smaller size molecules that cannot be removed by MF and UF membranes, however, they require much higher energy consumption during the 
operation due to high operating pressures. Therefore, low-pressure driven type of NF has been investigated for the removal of organic matter (Thanuttamavong et al., 2002; Shon et al., 2004).

There are many references regarding on the boundary of applications of different membranes (Mulder, 1996; Fane, 1996; Schafer, 2001). However, since the boundary of each membrane is uncertain, many researchers have used different definitions for the choice of membranes. Hence, it is necessary to put forward a detailed and clear definition for the pore size of the membrane. Table 18 presents the classification of different membranes, and thus would avoid overlapping of the definition of pore sizes for different membranes in terms of the tight and loose membranes.

Table 18 Size range of membrane separation process (adapted from Cho, 2006)

\begin{tabular}{lccccccc}
\hline \multicolumn{1}{c}{\begin{tabular}{c} 
Membrane \\
\multicolumn{1}{c}{ Process }
\end{tabular}} & \multirow{2}{*}{ RO } & Tight & Loose & Tight & Loose & Tight & Loose \\
\hline Molecular & $<150$ & 150 & 300 & 1000 & 10000 & 100000 & $0.01 \mu \mathrm{m}$ \\
Weight Cutoff & & to & to & to & to & dalton & to \\
(dalton) & & 300 & 1000 & 10000 & 100000 & to & $0.05 \mu \mathrm{m}$ \\
& & & & & & $0.01 \mu \mathrm{m}$ & \\
\hline
\end{tabular}

MF is the membrane process with the largest pores. It can be used to filter suspended particulates, large colloids and bacteria. The MF is also used as a pretreatment for NF and RO processes. Since the pore size of the MF is relatively large, air backflush or permeate backwash can be used to clean the deposits from the pores and the surface of the membrane. Physical sieving is the major rejection mechanism in MF. The deposit or cake on the membrane also acts as a self-rejecting layer, and thus MF can retain even smaller particles or solutes than its pore size (Chaudhary, 2003). 
UF enables the concentration, purification and fractionation of macromolecules such as proteins, dyes and other polymeric materials. It is widely used in the industrial wastewater treatment where recycling of raw materials, products and by-products are of primary concern. For example, it can be used to recover paints in the electrophoretic painting industries, lignin and lignosulforates from black liquor in the pulp and paper industry. UF is also used as a pretreatment to NF and RO processes (Schafer, 2001). UF and MF are also being used to replace many conventional filtration systems.

NF is referred as a low pressure RO. NF can remove $60-80 \%$ of hardness and more than $90 \%$ of color causing substances including all turbidity. NF has the advantage of a lower operating pressure as compared with RO yet has a higher rejection of organics as compared with UF. Both charge and size (molecular cutoff) are important in NF rejection. At a neutral $\mathrm{pH}$, most NF membranes are negatively charge, whereas at lower $\mathrm{pH}$, it is positively charged (Zhu and Elimelech, 1997). For the removal of ions and lower MW organics, chemical interactions between the solutes and membrane play an important role.

RO was the first membrane process to be widely commercialized. Reverse osmosis is the reversal of the natural process of osmosis in which water from a dilute solution passes through a semi-permeable membrane into a more concentrated solution due to osmotic pressure. In reverse osmosis, an external pressure greater than osmotic pressure is applied so that the water from concentrated solution passes into the diluted solution. 
Thus it can be used to separate salts and low MW pollutants from water and wastewater (Chaudhary, 2003). RO is used as the polishing treatment in water reclamation projects.

\subsubsection{Removal of EfOM by Membrane Technology}

Important characteristics that control the interactions with membrane include MW distribution, hydrophobic (aromatic) and hydrophilic (aliphatic) nature of EfOM, and (acidic) charge groups of EfOM. Similarly, molecular weight cutoff (MWCO), hydrophobicity and surface charge are important properties of membrane that can affect the interaction with EfOM. Three types of possible interactions between EfOM and membrane have been reported in the literature: i) adsorption (fouling), ii) electrostatic exclusion (rejection) and iii) steric exclusion (rejection) (Mulder, 1996). A number of researchers reported that for the negatively charged UF and NF, the characteristics of EfOM contributing to rejection include high MW and negative charge density. The other factors that can affect the EfOM rejection and membrane fouling are $\mathrm{pH}$, ionic strength and calcium content in the solution (Amy and Cho, 1999).

The EfOM removal by different membranes is shown in Table 19. In general, UF removes EfOM up to $40-60 \%$ and NF removes more than 80\%. Tables 20, 21 and 22 also show the removal of EDC and PPCP by MBR, UF and NF, respectively (Yoon et al., 2006; Snyder et al., 2006). The MBR gave marginal improvement in the treatment of organic contaminants as compared to the activated sludge (Snyder et al., 2006). The UF used in this study was 8000 daltons and $-32.2 \mathrm{mV}$ zeta potential (from Desal/Osmonics (GM membrane)). The pore size and the zeta potential of NF were 200 daltons and $-11.1 \mathrm{mV}$ 
(from Hydranautics (ESNA)). Since, the compounds of EDCs and PPCPs consist of the smallest MW from 150 to 500 daltons, UF could not remove these compounds. However, many steroid hormones showed significant removals through the UF membrane (Snyder et al., 2006). NF and RO can remove more than 90\% (Huang and Sedlak, 2001). Clearly, RO filtration is a superior technology for the removal of organic contaminants. However, at trace levels (i.e., ng/L) some compounds can still be detected in the RO permeate (Snyder et al., 2006). Polar and charged compounds are combined with other organic and inorganic compounds. These compounds led to better removal compared to less polar or neutral compounds (Snyder et al., 2003b). For instance, the removal of low MW increased at higher $\mathrm{pH}$ due to electrostatic repulsion and the removal of neutral compounds improved linearly with MW. Table 23 presents the removal of organic matter (in terms of DOC) by membrane processes with different pretreatments prior to membrane applications. 
Table 19 DOC removal by different membrane processes

\begin{tabular}{|c|c|c|c|}
\hline Researcher & Process & DOC removal & Wastewater \\
\hline $\begin{array}{lll}\text { Duin } & \text { et } \\
2000 & & \text { al., }\end{array}$ & $\begin{array}{l}\text { UF } \\
\text { NF (spiral wound) }\end{array}$ & $\begin{array}{l}10 \% \text { (COD) } \\
75-80 \% \text { (COD) }\end{array}$ & $\begin{array}{l}\text { Driebergen } \\
\text { BTSE, The } \\
\text { Netherlands }\end{array}$ \\
\hline $\begin{array}{l}\text { Jarusutthirak } \\
\text { and Amy, } \\
2001 \quad\end{array}$ & $\begin{array}{l}\text { UF (NTR 7410, } 20000 \text { Da) } \\
\text { UF (PM10, 10000 Da) } \\
\text { UF (GM, } 8000 \mathrm{Da}) \\
\text { NF (ESNA, } 200 \mathrm{Da})\end{array}$ & $\begin{array}{l}40 \% \\
25 \% \\
30 \% \\
92 \%\end{array}$ & $\begin{array}{l}\text { Boulder BTSE, } \\
\text { USA }\end{array}$ \\
\hline $\begin{array}{l}\text { Lee et al., } \\
2003\end{array}$ & $\begin{array}{l}\text { UF (T-8000, } 8000 \mathrm{Da}) \\
\text { UF (GM, 8000 Da) } \\
\text { NF (T-1000, 1000 Da) } \\
\text { NF (ESNA, 250) }\end{array}$ & $\begin{array}{l}38 \% \\
58 \% \\
40 \% \\
95 \%\end{array}$ & $\begin{array}{l}\text { Gwangju BTSE, } \\
\text { Korea }\end{array}$ \\
\hline $\begin{array}{l}\text { Ernst et al., } \\
2000\end{array}$ & $\begin{array}{l}\text { NF (DK5, 200) } \\
\text { NF (MP 35, 1000) } \\
\text { NF (NF-PES10, 1000) } \\
\text { NF (C5F, 5000) }\end{array}$ & $\begin{array}{l}96 \% \\
73 \% \\
67 \% \\
42 \%\end{array}$ & $\begin{array}{l}\text { Ruhleben BTSE, } \\
\text { Germany }\end{array}$ \\
\hline $\begin{array}{l}\text { Kishino et al., } \\
1996\end{array}$ & $\begin{array}{l}\text { SMBR (with activated } \\
\text { sludge) }\end{array}$ & $\begin{array}{l}98 \% \text { (BOD, from } \\
\text { activated sludge) }\end{array}$ & $\begin{array}{l}\text { Shinyodogawa } \\
\text { BTSE, Japan }\end{array}$ \\
\hline $\begin{array}{l}\text { Ahn and Song, } \\
1999\end{array}$ & $\begin{array}{l}\text { MBR with hollow fiber } \\
\text { membrane }(0.1 \mu \mathrm{m} \text {, with } \\
\text { activated sludge) }\end{array}$ & $92.8 \%$ (COD) & $\begin{array}{l}\text { KIST dormitory } \\
\text { BTSE, Korea }\end{array}$ \\
\hline $\begin{array}{l}\text { Gander et al., } \\
2000\end{array}$ & $\begin{array}{l}\text { SMBR* }(0.3-0.1 \mu \mathrm{m} \text { with } \\
\text { activated sludge }) \\
\text { Side stream }(0.1 \mu \mathrm{m}) \\
\text { Side stream }(50000 \mathrm{Da})\end{array}$ & $\begin{array}{l}86-97 \%(C O D) \\
\text { 98.7\% (COD) } \\
88-94.5 \%(C O D)\end{array}$ & Porlock, UK \\
\hline $\begin{array}{l}\text { Shon et al., } \\
2003\end{array}$ & $\begin{array}{l}\text { UF (NTR 7410, } 17500 \mathrm{Da}) \\
\text { NF (NTR 729HF, } 700 \mathrm{Da}) \\
\text { NF (LES 90, } 250 \mathrm{Da}) \\
\text { NF (LF 10, } 200 \mathrm{Da})\end{array}$ & $\begin{array}{l}44 \% \\
79 \% \\
91 \% \\
91 \%\end{array}$ & $\begin{array}{l}\text { Gwangju BTSE, } \\
\text { Korea }\end{array}$ \\
\hline
\end{tabular}

* SMBR: submerged membrane bioreactor 
Table 20 Removal during wastewater treatment using MBR (Snyder et al., 2006)

\begin{tabular}{|c|c|c|c|}
\hline & $\begin{array}{l}\text { WWTP influent } \\
\text { (ppt) }\end{array}$ & $\begin{array}{l}\text { WWTP effluent } \\
\text { (ppt) }\end{array}$ & $\begin{array}{l}\text { MBR effluent } \\
\text { (ppt) }\end{array}$ \\
\hline Hydrocodone & 118 & 168 & $<10$ \\
\hline Trimethoprim & 693 & 42 & $<10$ \\
\hline Acetaminophen & 172000 & $<10$ & $<10$ \\
\hline Caffeine & 72200 & 68 & $<10$ \\
\hline Erythromycin- $\mathrm{H}_{2} \mathrm{O}$ & 1050 & 800 & 34 \\
\hline Sulfamethoxazole & 1110 & 23 & $<10$ \\
\hline Fluoxetine & $<100$ & 44 & $<10$ \\
\hline Pentoxifylline & $<100$ & $<10$ & 30 \\
\hline Meprobamate & 966 & 652 & 1340 \\
\hline Dilantin & 210 & 192 & 184 \\
\hline Carbamazepine & 189 & 281 & $<10$ \\
\hline DEET & 150 & 213 & 171 \\
\hline Atrazine & $<100$ & $<10$ & $<10$ \\
\hline Diazepam & $<100$ & $<10$ & $<10$ \\
\hline Oxybenzone & 3810 & $<10$ & $<10$ \\
\hline Estriol & $<250$ & $<25$ & $<25$ \\
\hline Ethynylestradiol & $<100$ & $<10$ & $<10$ \\
\hline Estrone & $<250$ & $<25$ & $<25$ \\
\hline Estradiol & $<100$ & $<10$ & $<10$ \\
\hline Testosterone & $<100$ & $<10$ & $<10$ \\
\hline Progesterone & $<100$ & $<10$ & $<10$ \\
\hline Androstenedione & 150 & $<10$ & $<10$ \\
\hline Iopromide & $<100$ & $<10$ & $<10$ \\
\hline Naproxen & 12500 & 70 & $<10$ \\
\hline Ibuprofen & 12000 & 27 & 43 \\
\hline Diclofenac & $<100$ & 16 & $<10$ \\
\hline Triclosan & 1280 & 17 & $<10$ \\
\hline Gemfibrozil & 2210 & 74 & $<10$ \\
\hline
\end{tabular}


Table 21 Removal of EDC and PPCP by UF (adapted from Yoon et al., 2006; Snyder et al., 2006)

\begin{tabular}{lclc}
\hline EDC/PPCP & Removal (\%) & EDC/PPCP & Removal (\%) \\
\hline Acetaminophen & 63 & Genfibrozil & 0 \\
Androstenedione & 0 & Hydrocodone & 20 \\
Atrazine & 6 & Ibuprofen & 30 \\
Caffeine & 0 & Iopromide & 37 \\
Carbamzepine & 0 & Meprobamate & 0 \\
DEET & 0 & Naproxen & 72 \\
Diazepam & 7 & Oxybenzone & 83 \\
Diclofenac & 50 & Pentoxifylline & 0 \\
Dilantin & 0 & Progesterone-APCI & 0 \\
Erythromycin-H2O & 0 & Progesterone-ESI & 77 \\
Estrodiol & 0 & Sulfamethoxazole & 23 \\
Estriol & 0 & TCEP & 32 \\
Estrons & 14 & Testocterone & 0 \\
Ethynylestradiol & 98 & Triclosan & 93 \\
Fluoxetine & 0 & Trimethoprim & 0 \\
\hline
\end{tabular}


Table 22 Removal of EDC and PPCP by NF (adapted from Yoon et al., 2006, Snyder et al., 2006)

\begin{tabular}{lclc}
\hline EDC/PPCP & Removal (\%) & EDC/PPCP & Removal (\%) \\
\hline Acetaminophen & 82 & Genfibrozil & 15 \\
Androstenedione & 65 & Hydrocodone & 82 \\
Atrazine & 66 & Ibuprofen & 78 \\
Caffeine & 32 & Iopromide & 92 \\
Carbamzepine & 61 & Meprobamate & 32 \\
DEET & 58 & Naproxen & 89 \\
Diazepam & 75 & Oxybenzone & 97 \\
Diclofenac & 74 & Pentoxifylline & 66 \\
Dilantin & 19 & Progesterone-APCI & 62 \\
Erythromycin-H2O & 80 & Progesterone-ESI & 93 \\
Estrodiol & 0 & Sulfamethoxazole & 72 \\
Estriol & 63 & TCEP & 82 \\
Estrons & 65 & Testocterone & 50 \\
Ethynylestradiol & 77 & Triclosan & 97 \\
Fluoxetine & 92 & Trimethoprim & 43 \\
\hline
\end{tabular}


Table 23 DOC removal by membrane technology with pretreatment

\begin{tabular}{|c|c|c|c|}
\hline Researcher & Process & $\begin{array}{l}\text { DOC } \\
\text { removal }\end{array}$ & Wastewater \\
\hline $\begin{array}{l}\text { Jarusutthirak et } \\
\text { al., } 2002\end{array}$ & $\begin{array}{l}\text { MF + UF (GM, } 8000 \mathrm{Da}) \\
M F+\text { NF (ESNA, } 200 \mathrm{Da})\end{array}$ & $\begin{array}{l}75 \% \\
92 \%\end{array}$ & $\begin{array}{l}\text { St. Julien l'Ars } \\
\text { and Naintre } \\
\text { BTSE, France }\end{array}$ \\
\hline $\begin{array}{l}\text { Abdessemed } \\
\text { and Nezzal, } \\
2002\end{array}$ & $\begin{array}{l}\text { Flocculation }+ \text { adsorption }+ \text { UF } \\
(15000 \mathrm{Da})\end{array}$ & $96 \%(\mathrm{COD})$ & $\begin{array}{l}\text { Staoueli } \\
\text { Algeria }\end{array}$ \\
\hline $\begin{array}{l}\text { Lopez- } \\
\text { Ramirez et al., } \\
2003\end{array}$ & $\begin{array}{l}\text { Flocculation }+ \text { sand filter + UV } \\
\text { ray + RO (4040-MSY-CAB2, } \\
\text { Hydranautics) }\end{array}$ & $88 \%(\mathrm{COD})$ & $\begin{array}{l}\text { La Barrosa , } \\
\text { Chiclana de la } \\
\text { Frontera BTSE, } \\
\text { Spain }\end{array}$ \\
\hline $\begin{array}{l}\text { Kim et al., } \\
2002\end{array}$ & $\begin{array}{l}\text { UF }+ \text { RO (spiral wound, Fluid } \\
\text { systems, USA) } \\
\text { Dual media + GAC + RO } \\
\text { Dual media + GAC with a } \\
\text { coagulant + RO }\end{array}$ & $\begin{array}{l}79 \% \\
76 \% \\
64 \%\end{array}$ & $\begin{array}{l}\text { Local BTSE, } \\
\text { Singapore }\end{array}$ \\
\hline $\begin{array}{l}\text { Alonso et al., } \\
2001\end{array}$ & $\operatorname{MF}(0.2 \mu \mathrm{m})+\mathrm{UF}(50000 \mathrm{Da})$ & $50 \%(\mathrm{COD})$ & $\begin{array}{l}\text { Seville } \\
\text { Spain }\end{array}$ \\
\hline $\begin{array}{l}\text { Tchobanoglous } \\
\text { et al., } 1998\end{array}$ & $\begin{array}{l}\text { Media filter + Hollow fiber UF } \\
\text { (100000 Da) }\end{array}$ & $79 \%(\mathrm{COD})$ & Davis BTSE, USA \\
\hline $\begin{array}{l}\text { Chapman et } \\
\text { al., } 2002\end{array}$ & $\begin{array}{l}\text { Floating medium flocculator }+ \\
\text { MF }\left(0.2 \mu \mathrm{m}, \mathrm{CFMF}^{*}\right)\end{array}$ & $50 \%$ & $\begin{array}{l}\text { Olympic park } \\
\text { BTSE, Australia }\end{array}$ \\
\hline $\begin{array}{l}\text { Shon et al., } \\
2005\end{array}$ & $\begin{array}{l}\text { Flocculation + UF (NTR 7410, } \\
17500 \mathrm{Da}) \\
\text { Adsorption + UF (NTR 7410, } \\
17500 \mathrm{Da}) \\
\text { GAC biofiltration + UF (NTR } \\
7410,17500 \mathrm{Da}) \\
\text { Flocculation + adsorption + UF } \\
\text { (NTR 7410, 17500 Da) } \\
\text { Flocculation + adsorption + NF } \\
\text { (LES 90, } 250 \mathrm{Da})\end{array}$ & $\begin{array}{l}72 \% \\
78 \% \\
84 \% \\
90 \% \\
92 \%\end{array}$ & $\begin{array}{l}\text { Gwangju } \\
\text { Korea }\end{array}$ \\
\hline
\end{tabular}

* CFMF: crossflow microfiltration 


\section{Comparison of Different Treatment Methods used in EfOM Removal}

The removal of EfOM from BTSE depends significantly on the treatment processes used (Figure 6). The organic matter was considered in terms of DOC. PAC adsorption, GAC biofiltration, NF1 (700 daltons) and NF2 (200 daltons) relatively resulted in high DOC removal of EfOM compared to that of flocculation, IX, AOP and UF. This suggests that EfOM consists mainly of small MW organic matter in the BTSE used. 


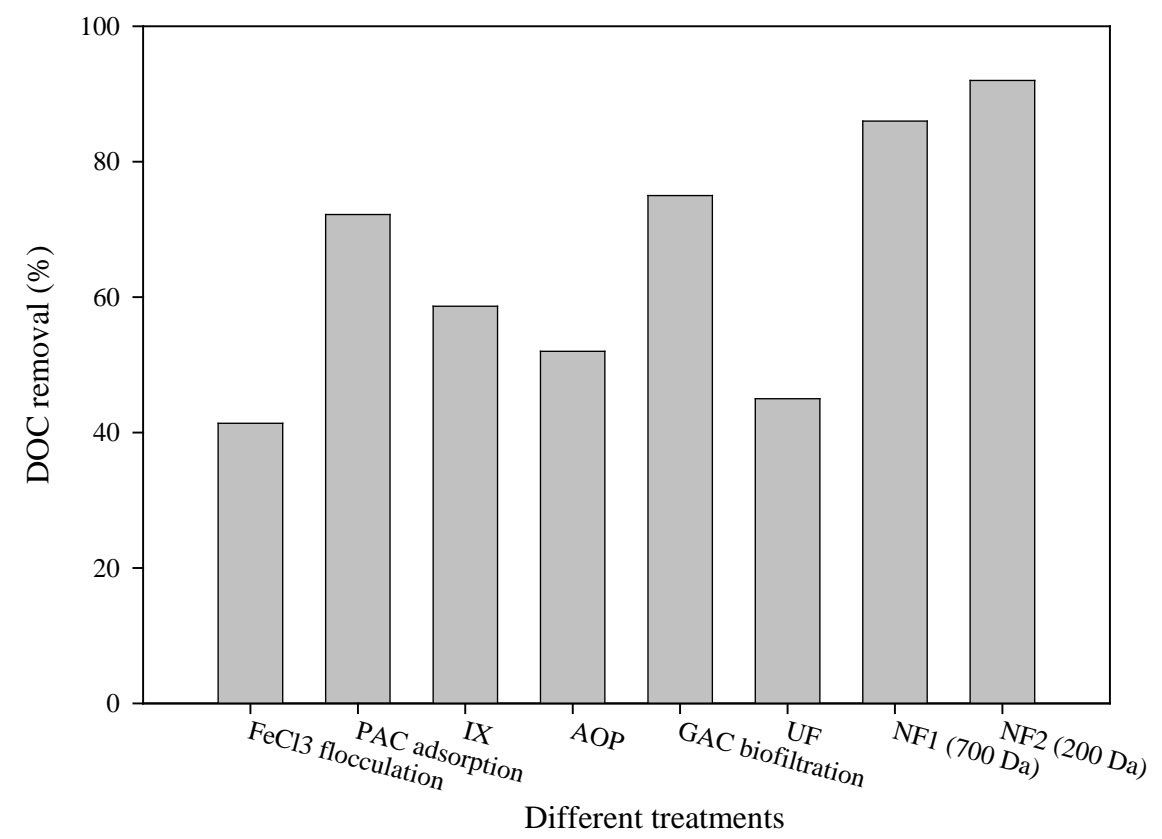

Figure 6 DOC removal by different processes $\left(\mathrm{FeCl}_{3}\right.$ flocculation, PAC adsorption, IX with $\mathrm{MIEX}{ }^{\circledR}$, AOP (photocatalysis) with $\mathrm{TiO}_{2}$, GAC biofiltration, UF (with 17500 daltons MWCO membrane), NF1 (with 700 daltons MWCO membrane) and NF2 (with 200 daltons MWCO membrane)) in biologically treated sewage effluent from a wastewater treatment plant (adapted from Shon et al., 2004 and 2005a)

Removals of different fractions are helpful to determine the efficiency of different treatments in removing hydrophobic (HP), transphilic (TP) and hydrophilic (HL) fractions (Table 24). $\mathrm{FeCl}_{3}$ flocculation removed higher amount of HL fraction. This is probably due to the ionic effects of EfOM. The flocculation removes the HL fraction when the pollutants are more negative charged. In general, flocculation and adsorption are used mainly to remove HP of large and small MW organics. The removal of HL by flocculation (in this case) may be due to the large dose of $\mathrm{FeCl}_{3}$ used (through sweep flocculation mechanism) (Shon et al., 2005a). The removal of HL by adsorption could be attributed to 
the physical affinity between HL organic molecules and PAC (through Vander Waals, electro static forces and chemisorption) (Shon et al., 2004). Ion exchange with MIEX ${ }^{\circledR}$ also exhibited very high removal of hydrophilic compounds (Zhang et al., 2005).

Table 24 Efficiency of different treatment processes in the removal of different fractions from BTSE

\begin{tabular}{lccccc}
\hline & $\begin{array}{c}\text { Initial } \\
(\mathrm{mg} / \mathrm{L})\end{array}$ & MIEX $^{(}(\mathrm{mg} / \mathrm{L})$ & $\begin{array}{c}\text { PAC adsorption } \\
(\mathrm{mg} / \mathrm{L})\end{array}$ & $\begin{array}{c}\text { Flocculation } \\
(\mathrm{mg} / \mathrm{L})\end{array}$ & $\begin{array}{c}\text { Photocatlysis } \\
(\mathrm{mg} / \mathrm{L})\end{array}$ \\
\hline HP & 1.645 & $0.715(56.5 \%)$ & $0.460(72.0 \%)$ & $0.999(39.3 \%)$ & $0.802(51.2 \%)$ \\
TP & 1.034 & $0.705(31.8 \%)$ & $0.282(72.7 \%)$ & $0.802(22.4 \%)$ & $0.703(32.0 \%)$ \\
HL & 3.822 & $1.180(69.1 \%)$ & $1.258(67.1 \%)$ & $1.540(59.7 \%)$ & $2.810(26.5 \%)$ \\
\hline
\end{tabular}

MW distribution of EfOM is very important in the understanding of the removal of different size ranges of pollutants by different treatment methods. The MW distribution was measured using high pressure size exclusion chromatography (HPSEC, Shimadzu Corp., Japan) with a SEC column (Protein-pak 125, Waters Milford, USA). The separation ranges are from 1000 to about 50000 daltons. The effluent was made of pure water with phosphate (pH 6.8) and $\mathrm{NaCl}(0.1 \mathrm{M})$. The detection limit of $\mathrm{UV}$ was 0.001 per cm. Standards of MW of various polystyrene sulfonates (PSS: 210, 1800, 4600, 8000 , and 18000 daltons) were used to calibrate the equipment. The details of these experiments are given elsewhere (Her, 2002).

Figure 7 presents the MW distribution of EfOM after different treatments. The MW distribution of EfOM in the BTSE used is comprised of small (263 daltons, 580 and 865) and large (43110 daltons) MW compounds. Flocculation removed mainly the large MW compounds and did not remove the majority of small MW (263 daltons, 330 and 
580). Adsorption mainly removed the small MW compounds, however, NF removed practically all MW ranges of EfOM. 

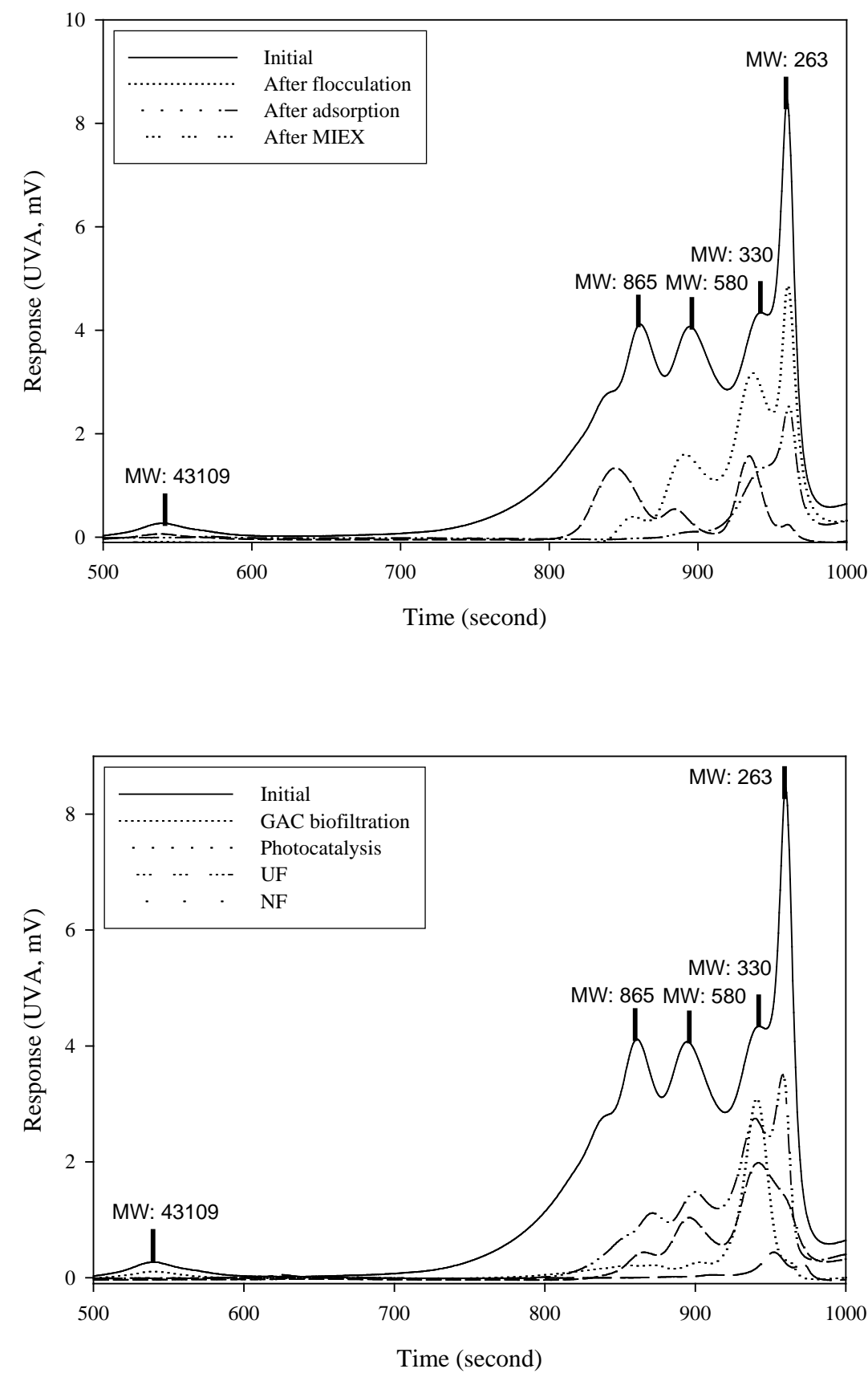

Figure $7 \mathrm{MW}$ distribution of the influent BTSE and effluents from different treatments (flocculation, adsorption, GAC biofiltration, photocatalysis, MIEX ${ }^{\circledR}$, UF and NF)

It is difficult to remove EDCs and PPCPs in EfOM within the range from 100 to 500 daltons. Removal of EDCs and PPCPs thus is considered as the decisive parameter in 
determining the efficiency of a particular treatment. Considering treatments of flocculation, adsorption and oxidation, the removal of these compounds showed very different trends (Table 25). Some of them are removed by up to $90 \%$, while the others can only be partially removed. This suggests that removal of the emerging contaminants requires the careful selection of treatment methods depending on the individual EDC and PPCP structure and treatment application/dose.

Table 25 Unit processes and operations used for EDC and PPCP removal in WWTP (adapted from Barceló, 2003)

\begin{tabular}{|c|c|}
\hline Treatments & Compounds \\
\hline Flocculation & $\begin{array}{l}>50 \% \text { removal of: } \quad \begin{array}{c}\text { benzo[a]pyrene, } \\
\text { mirex, }\end{array} \\
\begin{array}{l}\text { benzo[k]fluoranthene, } \\
\text { benzo[a]anthracene } \\
<10 \% \text { removal of: diazepam, diclofenac, meprobamate, } \\
\text { sulfamethoxazole, trimethoprim }\end{array}\end{array}$ \\
\hline Adsorption & $\begin{array}{l}>90 \% \text { removal of: triclosan, fluoxetine, oxybenzone, mirex, DDT } \\
<50 \% \text { removal: meprobamate, sulfamethoxazole, iopromide, } \\
\text { trimethoprim, gemfibrozil }\end{array}$ \\
\hline Chlorination & $\begin{array}{l}>90 \% \text { removal of: } 17 \beta \text {-estradiol, oxybenzone, triclosan, } \\
\text { sulfamethoxazole, benzo[a]anthracene } \\
<40 \% \text { removal of: androstenedione, progesterone, DDT, tri(2- } \\
\text { chloroethyl) phosphate, mirex }\end{array}$ \\
\hline Ozonation & $\begin{array}{l}>90 \% \text { removal of: } 17 \beta \text {-estradiol, fluoxetine, carbamazepine, } \\
\text { progesterone, trimethoprim } \\
<50 \% \text { removal of: lindane, musk ketone, iopromide, TCEP, } \\
\text { meprobamate }\end{array}$ \\
\hline
\end{tabular}

Table 26 presents the universal performance of different unit processes in removing typical classes of EDC and PPCP. RO and NF membranes remove the majority of contaminants. However, the removal of these compounds by different treatment methods depends on the characteristics of each compound. 
Table 26 Unit processes and operations used for EDC and PPCP removal (adapted from Snyder et al., 2003b)

\begin{tabular}{|c|c|c|c|c|c|c|c|}
\hline Group & Classification & $\mathrm{AC}$ & $\mathrm{O}_{3} / \mathrm{AOP}$ & $\mathrm{Cl}_{2} / \mathrm{ClO}_{2}$ & Flocculation & NF & RO \\
\hline \multirow[t]{6}{*}{ EDC } & Pesticides & $\mathrm{E}$ & L-E & P-E & $\mathrm{P}$ & G & E \\
\hline & Industrial chemicals & $\mathrm{E}$ & F-G & $\mathrm{P}$ & P-L & $\mathrm{E}$ & $\mathrm{E}$ \\
\hline & Steroids & $\mathrm{E}$ & $\mathrm{E}$ & E & $\mathrm{P}$ & G & $\mathrm{E}$ \\
\hline & Metals & G & $\mathrm{P}$ & $\mathrm{P}$ & F-G & G & $\mathrm{E}$ \\
\hline & Inorganics & P-L & $\mathrm{P}$ & $\mathrm{P}$ & $\mathrm{P}$ & G & E \\
\hline & Organometallics & G-E & L-E & P-F & P-L & G-E & $\mathrm{E}$ \\
\hline \multirow[t]{6}{*}{ РPCР } & Antibiotics & F-G & L-E & P-G & P-L & $\mathrm{E}$ & $\mathrm{E}$ \\
\hline & Antidepressants & G-E & L-E & P-F & P-L & G-E & $\mathrm{E}$ \\
\hline & Anti-inflammatory & $\mathrm{E}$ & $\mathrm{E}$ & P-F & $\mathrm{P}$ & G-E & $\mathrm{E}$ \\
\hline & Sunscreens & G-E & L-E & P-F & P-L & G-E & $\mathrm{E}$ \\
\hline & Antimicrobials & G-E & L-E & P-F & P-L & G-E & $\mathrm{E}$ \\
\hline & Surfactants/detergents & $\mathrm{E}$ & F-G & $P$ & P-L & $\mathrm{E}$ & $\mathrm{E}$ \\
\hline
\end{tabular}

AC, activated carbon; E, excellent (>90\%); G, good (70-90\%); F, fair (40-70\%); L, low (20-40\%); P, poor $(<20 \%)$

\section{Concluding Remarks}

Although a number of studies have dealt with characteristics of natural organic matter in surface waters, there have not been many studies of effluent organic matter (EfOM) originating from biologically treated sewage effluent. EfOMs consist of natural organic 
matter, soluble microbial products, persistent organic matters and trace pollutants such as emerging pollutants such as endocrine disrupting chemicals (EDCs) and pharmaceuticals and personal care products (PPCPs). Most of natural organic matter in EfOM originates from tap water and soluble microbial products are a by-product of biological treatment.

Extracellular polymeric substances and soluble microbial products produced during biological treatment are important because they constitute the majority of EfOMs. Proteins, carbohydrates, fat, oil and grease are the constituents of EfOM which are often found in wastewater. These compounds lead to disinfection by-products upon disinfection, membrane fouling, sludge bulking in activated sludge (biological treatment), clogging of sewer pipes, floating matter and films in waterways.

The efficiency of different treatments (flocculation, adsorption, biofiltration, ion exchange, advanced oxidation process and membrane technology) has been investigated in terms of dissolved organic matter removal, fraction removal (preferential removal of hydrophobicity), EDC/PPCP removal (representation of smallest MW compounds) and MW distribution (different MW sizes). PAC adsorption, GAC biofiltration, NF with 700 daltons MWCO and NF with 200 daltons MWCO resulted in high organic removal of EfOM compared to that of flocculation, ion exchange, advanced oxidation process and UF. This suggests that EfOM consists mainly of small MW organic matter in the biologically treated sewage effluent used. In terms of removal of hydrophobic, transphilic and hydrophilic fraction, $\mathrm{FeCl}_{3}$ flocculation removed relatively high amounts of the hydrophilic fraction. PAC adsorption preferentially removed hydrophobic fraction. 
It is difficult to remove EDCs and PPCPs in EfOM in the ranges from 100 to 500 daltons with conventional treatments. The removal of these compounds with the treatments of flocculation, adsorption and oxidation shows different trends. Some of them were removed by up to $90 \%$, while the others showed minor removal. The RO and NF membranes removed the majority of the EDC and PPCP. The removal of these compounds by different treatment methods also depended on the characteristics of individual compound. This proposes that the removal of the emerging contaminants requires the careful selection of treatment method and this depends on the individual EDC and PPCP compounds.

MW distribution of EfOM was investigated before and after different treatments. Flocculation mainly removed the large MW compounds and did not remove the majority of small MW (263 daltons, 330 and 580). Adsorption essentially removed the small MW compounds. However, NF removed practically all MW ranges of EfOM. Thus, MW distribution can give useful information in the selection of appropriate treatment methods.

Trace chemicals such as EDCs and PPCPs are becoming a major concern. Nonetheless, the efficiency of removing the majority of these compounds by different treatment processes is still unknown due to the sensitive analytical methods. In addition, the investigation of the toxicity of these compounds is becoming an important and urgent issue and therefore, this review recommends the development of sensitive analysis of specific compounds and their toxicity. 


\section{Acknowledgements}

The first author sincerely appreciates the support of the Kwanjeong Educational Foundation for a scholarship. This study is supported by the UTS research grant.

\section{References}

Abdessemed D, Nezzal G. (2002) Treatment of primary effluent by coagulationadsorption-ultrafiltration for reuse. Desalination 152 (1-3), 367-373.

Adams C., Wang Y., Loftin K., and Meyer M. (2002) Removal of antibiotics from surface and distilled water in conventional water treatment processes. Journal of Enviromental Engineering 123, 253-260.

Adin A., Soffer Y. and Ben Aim R. (1998) Effluent pre-treatment by iron coagulation applying various dose-pH combinations for optimum particle separation. Water Science and Technology 38 (5), 27-34.

Ahn K.H. and Song K.G. (1999) Treatment of domestic wastewater using microfiltration for reuse of wastewater. Desalination 126 (1-3), 7-14. 
Al-Bastaki, N.M. (2003) Performance of advanced methods for treatment of wastewater: UV/TiO, $\mathrm{RO}$ and UF. Chemical Engineering and Processing, 43 (7), 935-940.

Alcock R. E., Sweetman A., et al. (1999) Assessment of Organic Contaminant Fate in Waste Water Treatment Plants. Chemosphere 38(10), 2247-2262.

Alonso E., Santos A., Solis G.J. and Riesco P. (2001) On the feasibility of urban wastewater tertiary treatment by membranes: a comparative assessment. Desalination 141 (1), 39-51.

Amy G. and Cho J. (1999) Interactions between Natural Organic Matter (NOM) and Membranes : Rejection and Fouling. Water Science and Technology 40 (9), 131139.

Ankley G., Mihaich E., et al. (1998) Overview of a Workshop on Screening Methods for Detecting Potential (Anti-) Estrogenic/Andogenic Chemicals in Wildlife. Environmental Toxicology and Chemistry 17(1), 68-87.

Barceló D. (2003) Emerging pollutants in water analysis. TrAC Trends in Analytical Chemistry 22 (10), xiv-xvi.

Barker D.J. and Stuckey D.C. (2001) Modeling of soluble microbial products in anaerobic digestion: the effect of feed strength and composition. Water Environ Res 73 (2), 173-184.

Bevans H. E., Goodbred S. L., et al. (1996) Synthetic Organic Compounds and Carp Endocrinology and Histology in Las Vegas Wash and Las Vegas and Callville Bays of Lake Mead, Nevada, 1992 and 1995. Water-Resources Investigations Report 96-4266. 
Bolto B., Dixon D. and Eldridge R. (2004) Ion exchange for the removal of natural organic matter. Reactive and Functional Polymers, 60, 171-182.

Bourke M, Slunjski M, O Leary B, Smith P, (1999) Scale-Up of the MIEX DOC Process for Full Scale Water Treatment Plants, $18^{\text {th }}$ Federal Convention AWWA Procedings 99, Adelaide.

Boyd G.R., Reemtsma H., Grimm D.A. and Mitra S. (2003) Pharmaceuticals and personal care products (PPCPs) in surface and treated waters of Louisiana, USA and Ontario, Canada. The Science of The Total Environment, 311 (1-3), 135-149.

Brattebo H, Odegaard H, Halle O, (1987) Ion Exchange for the Removal of Humic Acids in Water Treatment. Water Research 21 (9), 1045-1052.

Chapman H., Vigneswaran S., Ngo H.H., Dyer S., and Ben Aim R. (2002) Preflocculation of secondary treated wastewater in enhancing the performance of microfiltration. Desalination 146, 367-372.

Chaudhary D.S. (2003) Adsorption - Filtration Hybrid System in Wastewater Treatment and Reuse, Doctoral thesis of philosophy, University of Technology, Sydney.

Cho J. (2006) membrane selection guide. http://env1.kjist.ac.kr/cgibin/kimsboard/kimsboard.cgi?db=nom_news\&action=view\&file=2425961.cgi\&re $=0 \& n o=31 \& p=3$.

Cho, J. Natural organic matter (NOM) rejection by, and flux-decline of , nanofiltration (NF) and ultrafiltration (UF) membranes. Ph.D. dissertation, Department of Civil, Environmental, and Architectural engineering, University of Colorado at Boulder, 1998. 
Choo K.H. and Kang S.K. (2003) Removal of residual organic matter from secondary effluent by iron oxides adsorption. Desalination 154 (2), 139-146.

Chu W. and Wong C.C. (2004) The photocatalytic degradation of dicamba in $\mathrm{TiO}_{2}$ suspensions with the help of hydrogen peroxide by different near UV irradiations. Water Research 38 (4), 1037-1043.

Clancy J.L. and Hargy T.M. (2004) UV inactivation of microorganisms in water - a review. Water Journal, 31 February, 19-21.

Cook J. W., Dodds E. C., et al. (1934) Estrogenic activity of some condensed ring compounds in relation to their other biological activities. Proceedings of the Royal Society of London B114, 272-286.

Daughton C. G. and Ternes T. A. (1999) Pharmaceuticals and Personal Care Products in the Environment: Agents of Subtle Change? Environmental Health Perspectives 107(6), 907-938.

del Rio J.C., McKinney D.E., Knicker H., Nanny M.A., Minard R.D. and Hatcher P.G. (1998) Structural characterization of bio- and geo-macromolecules by off-line thermochemolysis with tetramethylammonium hydroxide. Journal of Chromatography A 823 (1-2), 433-448.

Desbrow C., Routledge E. J., et al. (1998) Identification of Estrogenic Chemicals in STW Eflleunt. 1. Chemical Fractionation and in Vitro Biological Screening. Environmental Science \& Technology 32(11), 1549-1558.

DeWolfe J., Dempsey B., Taylor M. and Potter J.W. (2003) Guidance manual for coagulant changeover. AWWA Research foundation, Denver. 
Dignac M.F., Ginestet P., Ryback D., Bruchet A., Urbain V. and Scribe P. (2000) Fate of wastewater organic pollution during activated carbon sludge treatment: nature of residual organic matter. Water Research 37, 4185-4194.

Drewes J. and Fox P. (1999) Fate of Natural Organic Matter (NOM) during Groundwater Recharge using Reclaimed Water. Water Science and Technology, 40 (9), 241-248.

Drewes J. E., Heberer T., et al. (2002) Fate of pharmaceuticals during indirect potable reuse. Water Science and Technology 46(3), 73-80.

Duin O., Wessels P., van der Roest H., Uijterlinde C. and Schoonewille H. (2000) Direct nanofiltration or ultrafiltration of WWTP effluent? Desalination 132 (1-3), 65-72.

Ellis T.G. (2004) Chemistry of wastewater. Encyclopedia of Life Support System (EOLSS), Developed under the Auspices of the UNESCO, Eolss Publishers, Oxford, UK, http://www.eolss.net.

Ernst M., Sachse A., Steinberg C.E.W. and Jekel M. (2000) Characterization of the DOC in nanofiltration permeates of a tertiary effluent. Water Research 34 (11), 2879-2886.

Fane A.G. (1996) Membrane for water production and wastewater reuse. Desalination 106, 1-9.

Fearing D.A., Banks J., Guyetand S., Eroles C.M., Jefferson B., Wilson D., Hillis P., Campbell A.T. and Parsons S.A. (2004) Combination of ferric and MIEX ${ }^{\circledR}$ for the treatment of a humic rich water. Water Research 38 (10), 2551-2558.

Fisher A. L., Keasling H. H., et al. (1952) Estrogenic action of some DDT analogs. Proc. Soc. Exptl. Biol. Med. 81, 439-441. 
Fontanier V., Farines V., Albet J., Baig S. and Molinier J. (2006) Study of catalyzed ozonation for advanced treatment of pulp and paper mill effluents. Water Research, 40 (2), 303-310.

Frederick K, (1997) A Look at Uniform Ion-Exchange Resins Ultrapure Water, Sep 1997, 66-67.

Gander M., Jefferson B. and Judd S. (2000) Aerobic MBRs for domestic wastewater treatment: a review with cost considerations. Separation and Purification Technology 18 (2), 119-130.

Garrison A. W., Pope J. D., et al. (1975) GC/MS analysis of organic compounds in domestic wastewaters. Chem. Congr. North Am. Cont., Ann Arbor Science.

Gillesby B. E. and Zacharewski T. R. (1998) Exoestrogens: Mechanisms of action and strategies for identification and assessment. Environmental Toxicology and Chemistry 17(1), 3-14.

Goel S., Hozalski R. M., and Bouwer E. J. (1995) Biodegradation of NOM: effect of NOM source and ozone dose, Journal of American Water Works Association 87 (1), 90.

Gogate P.R. and Pandit A.B. (2003) A review of imperative technologies for wastewater treatment I: oxidation technologies at ambient conditions. Advances in Environmental Research 8 (3-4), 501-551.

Gottlieb M. (1996) The Reversible Removal of Naturally Occuring Organics Using Resins Regenerated with Sodium Chloride, Ultrapure Water Nov 1996, 53-58.

Halling-Sorensen B., Nielsen S. N., et al. (1998) Occurence, Fate and Effects of Pharmaceutical Substances in the Environment - A Review. Chemosphere 36(2), 357-393. 
Hammann D., Bourke M. and Topham C. (2004) Magnetic ion exchange resin exceeds EPA disinfection byproduct (DBP) standards. Filtration \& Separation 41 (4), 2830.

Harries J. E., Sheahan D. A., et al. (1997) Estrogenic activity in five United Kingdom rivers detected by measurement of vitellogenesis in caged male trout. Environmental Toxicology and Chemistry 16(3),534-542.

Her N., Amy G., Foss, D.; Cho, J.; Yoon, Y.; Kosenka, P. (2002) Optimization of method for detecting and characterizing NOM by HPLC-size exclusion chromatography with UV and on-line DOC detection. Environmental Science \& Technology 36(5): 1069-1076.

Her, N.G. Identification and characterization of foulants and scalants on NF membrane. Ph.D. dissertation, Department of Civil, Environmental, and Architectural engineering, University of Colorado at Boulder, 2002.

Hignite C. and Azarnoff D. L. (1977) Drugs and drug metabolites as environmental contaminants: chlorophenoxyisobutyrate and salicylic acid in sewage water effluent. Life Sciences 20(2), 337-341.

Huang C.H. and Sedlak D.L. (2001) Analysis of estrogenic hormones in municipal wastewater effluent and surface water using ELISA and GC/MS/MS. Environmental Toxicology and Chemistry 20, 133-139.

Ito K., Jian W. Nishijima W., Baes A.U., Shoto E. and Okada M. (1998) Comparison of ozonation and AOPs combined with biodegradation for removal of THM precursors in treated sewage effluents. Water Science and Technology 38 (7), 179-186. 
Jarusutthirak C. (2002) Fouling and flux decline of reverse osmosis (RO), nanofiltration (NF) and ultrafiltration (UF) membranes associated with effluent organic matter (EfOM) during wastewater reclamation/reuse. Ph. D. Dissertation, University of Colorado at Boulder.

Jarusutthirak C. and Amy G. (2001) Membrane filtration of wastewater effluents for reuse: effluent organic matter rejection and fouling. Water Science and Technology 43 (10), 225-232.

Jarusutthirak C., Amy G. and Croué J.-P. (2002) Fouling characteristics of wastewater effluent organic matter (EfOM) isolates on NF and UF membranes. Desalination 145 (1-3), 247-255.

Jobling S., Casey D., et al. (2003) Comparative responses of molluscs and fish to environmental estrogens and an estrogenic effluent. Aquatic Toxicology 65(2), 205-220.

Jobling S., Coey S., et al. (2002) Wild intersex roach (Rutilus rutilus) have reduced fertility. Biology of Reproduction 67(2), 515-524.

Kahn S. (2004) Identifying impediments to municipal water recycling in Australia. Enviro 04 Convention \& Exhibition, Sydney, 28 March - 1 April.

Kim S.L., Chen J.P. and Ting Y.P. (2002) Study on feed pre-treatment for membrane filtration of secondary effluent. Separation and Purification Technology 29, 171179.

Kishino H., Ishida H., Iwabu H. and Nakano I. (1996) NakanoDomestic wastewater reuse using a submerged membrane bioreactor. Desalination 106 (1-3), 115-119. 
Kolpin D. W., Furlong E. T., et al. (2002) Pharmaceuticals, Hormones, and Other Organic Waste Contaminants in U.S. Streams, 1999-2000: A National Reconnaissance. Environmental Science \& Technology 36(6), 1202-1211.

Kramer V. J., Miles-Richardson S., et al. (1998) Reproductive impairment and induction of alkaline-labile phosphate, a biomarker of estrogen exposure, in fathead minnows (Pimephales promelas) exposed to waterborne 17b-estradiol. Aquatic Toxicology 40, 335-360.

Kumar V., Wati L., Nigam P., Banat I.M., Yadav B.S., and Singh D. (1998) Decolorization and biodegradatioin of anaerobically digested sugarcane molasses spent ash effluent from biomethanation plants by white rot fungi. Process Bio. Cycle 39, 64-72.

Lee S., Cho Y.G., Song Y., Kim I.S. and Cho J. (2003) Transport characteristics of wastewater effluent organic matter in nanofiltration and ultrafiltration membranes. Journal of Water Supply 52 (2), 129-139.

Leenheer J. A. and Croue J.-P. (2003) Characterizing aquatic dissolved organic matter. Environmental Science \& Technology 37(1), 18A-26A.

Levine A.D., Tchobanoglous G. and Asano T. (1985) Characterization of the size distribution of contaminants in wastewater: treatment and reuse implications, Journal WPCF 57 (7), 805-816.

Lindqvist N., Tuhkanen T., et al. (2005) Occurrence of acidic pharmaceuticals in raw and treated sewages and in receiving waters. Water Research 39, 2219-2228.

López-Ramírez J.A., Sahuquillo S., Sales D. and Quiroga J.M.(2003) Pre-treatment optimisation studies for secondary effluent reclamation with reverse osmosis. Water Research 37 (5), 1177-1184. 
Metcalf and Eddy, Wastewater Engineering: Treatment, Disposal and Reuse, $3^{\text {rd }}$ edition, Revised by Tchobanoglous, G. and Burton, F., McGraw-Hill, Inc., Singapore, 1991.

Meyers P., (1995) Operating Experiences with a New Organic Trap Resin, International Water ConferenceProceedings 1995,

Molinari R., Borgese M., Drioli E., Palmisano L. and Schiavello M. (2002) Hybrid processes coupling photocatalysis and membranes for degradation of organic pollutants in water. Catalysis Today 75 (1-4), 77-85.

Molinari R., Grande C., Drioli E., Palmisano L. and Schiavello M. (2001) Photocatalytic membrane reactors for degradation of organic pollutants in water. Catalysis Today 69, 273-279.

Mulder M. Basic principles of membrane technology ( $2^{\text {nd }}$ edition). Boston: Kluwer Academic Publishers, 1996.

Müller M.B., Schmitt D., Frimmel, F.H. (2000) Fractionation of natural organic matter by size exclusion chromatography - properties and stability of fractions. Environmental Science \& Technology 34 (23): 4867-4872.

Najm I.N., Snoeyink V.L., Suidan M. T., Lee C.H. and Richard Y. (1990) Effect of particle size and background natural organics on the adsorption efficiency of PAC. Journal of American Water Works Association 82 (1), 65-72.

Namkung E. and Rittmann B.E. (1986) Soluble microbial products (SMP) formation kinetics by biofilms. Water Research 20 (6), 795-806.

Noguera D.R., Araki N. and Rittmann B.E. (1994) Soluble microbial products (SMP) in anaerobic chemostats. Biotechnol Bioeng 44, 1040-1047. 
Painter H.A. (1973) Organic compounds in solution in sewage effluents. Chem. Ind. September, 818-822.

Parkin G.F. and McCarty P.L. (1981) Production of soluble organic nitrogen during activated sludge treatment. J. WPCF 53 (1), 99-112.

Parrott J. L. and Blunt B. R. (2005) Life-cycle exposure of fathead minnows (Pimephales promelas) to an ethinylestradiol concentration below $1 \mathrm{ng} / \mathrm{L}$ reduces egg fertilization success and demasculinizes males. Environmental Toxicology 20(2), 131-141.

Pawar N.J., Pondhe G.M. and Patil S.F. (1998) Groundwater pollution due to sugar-mill effluent, at Sonai, Maharashtra. India. Environ. Geol. 34, 151-160.

Pempkowiak J. and Obarska-Pempkowiak H. (2002) Long-term changes in sewage sludge stored in a reed bed. The Science of the Total Environment 297, 59-65.

Petrović M., Gonzalez S. and Barceló D. (2003) Analysis and removal of emerging contaminants in wastewater and drinking water. TrAC Trends in Analytical Chemistry 22 (10), 685-696.

Pirkanniemi K. and Sillanpää M. (2002) Heterogeneous water phase catalysis as an environmental application: a review. Chemosphere 48 (10) 1047-1060.

Rachwal A.J., Bauer M.J., Chipps M.J., Colbourne J. S. and Foster D. M. Comparisons between slow sand and high rate biofiltration. In: advances in slow sand and alternative biological filtration. Edited by Graham, N. and Collins, R., John Wiley \& Sons Ltd., Chichester, England, 1996.

Rebhun M. Meir S. and Laor Y. (1998) Using dissolved humic acid to remove hydrophobic contaminants from water by complexation-flocculation process. Environmental Science and Technology 32, 981-986. 
Renner R. (1998). Human estrogens linked to endocrine disruption. Environmental Science \& Technology 32(1), 8A.

Réveillé V., Mansuy L., Jardé Ė., and Garnier-Sillam Ė (2003) Characterisation of sewage sludge-derived organic matter: lipids and humic acids. Organic Geochemistry 34 (4), 615-627.

Rittmann B.E. and McCarty P.L. (2001) Environmental biotechnology: principles and applications. , McGraw-Hill International Editions, London, UK.

Rittmann B.E., Bae W., Namkung E. and Lu C.J. (1987) A critical evaluation of microbial product formation in biological processes. Water Sci Technol 19, 517528.

Roila T., Kortelainen P., David M.B. and Makinen I. (1994) Acid-base characteristics of DOC in Finnish lakes. In: Senesi, N., Miano, T.M. (eds) Humic substances in the global environment and implications for human health. Elsevier, Amsterdam, 863868.

Sacher F., Haist-Gulde B., Brauch H.-J., Preub G., Wilme U., Zullei-Seibert N., Meisenheimer M., Welsch H. and Ternes T.A. (2000) Behavior of selected pharmaceuticals during drinking water treatment. 219th ACS Nationtal Meeting, San Francisco, CA, 116-118.

Schafer A.I. (2001) Natural organics removal using membranes: principles, performance, and cost. Technomic Publishing Company, Inc., Pennsylvania, USA

Schueler F. W. (1946) Sex-hormonal action and chemical constitution. Science 103: 221-223.

Shon H.K., Nathaporn A., Vigneswaran S., Ngo H.H. and Kim J.-H. (2005b) Photocatalysis hybrid system in the removal of effluent organic matter (EfOM). 
International Conference on Advances in Industrial Wastewater Treatment, 9 - 11 February, Chennai, India.

Shon H.K., Vigneswaran S., Ben Aim R., Ngo H. H., Kim In S. and Cho J. (2005) Influence of flocculation and adsorption as pretreatment on the fouling of ultrafiltration and nanofiltration membranes: application with biologically treated sewage effluent. Environmental Science \& Technology, 39 (10), 3864-3871.

Shon H.K., Vigneswaran S., Kim I.S., Cho J. and Ngo H.H. (2004) The effect of pretreatment to ultrafiltration of biologically treated sewage effluent: a detailed effluent organic matter (EfOM) characterization. Water Research 38 (7), 1933-1939.

Shon H.K., Vigneswaran S., Ngo H.H., Kim D.H., Park N.E., Jang N.J. and Kim I.S. (2003) Characterization of effluent organic matter (EfOM) of fouled nanofilter (NF) membranes, International membrane science and technology (IMSTEC) proceedings, Sydney, Australia.

Slunjski M., Bourke M., Nguyen H., Morran J. and Bursill D. (1999) MIEX® DOC Process - A New Ion Exchange. 18th Federal Convention, Australian Water \& Wastewater Association, Proceedings 11-14 April 1999, Adelaide Australia. http://www.orica.com/Business/CHE/CHLORALKALI/WCHE00017.nsf/ 0/699ce37915caf471ca256cd000226362/

Snyder S. A., Keith T. L., et al. (1999) Analytical methods for detection of selected estrogenic compounds in aqueous mixtures. Environmental Science \& Technology 33(16), 2814-2820.

Snyder S. A., Keith T. L., et al. (2001a) Bioconcentration of nonylphenol in fathead minnows (Pimephalas promelas). Chemosphere 44(8), 1697-1702. 
Snyder S. A., Keith T. L., et al. (2001b) Identification and quantification method for nonylphenol and lower oligomer nonylphenol ethoxylates in fish tissues. Environmental Toxicology and Chemistry 20(9), 1870-1873.

Snyder S. A., Kelly K. L., et al. (2001c) Pharmaceuticals and personal care products in the waters of Lake Mead, Nevada. Pharmaceuticals and Personal Care Products in the Environment: Scientific and Regulatory Issues. C. G. Daughton and T. L. Jones-Lepp. Washington,D.C., American Chemical Society. Symposium Series 791, 116-140.

Snyder S. A., Villeneuve D. L., et al. (2001d) Identification and quantification of estrogen receptor agonists in wastewater effluents. Environmental Science \& Technology 35(18), 3620-3625.

Snyder S., Vanderford B., Pearson R., Quiñones and Yoon Y. (2003a) Analytical method used to measure endocrine disrupting compound in water. Practice Periodical of Hazardous, Toxic, and Radioactive waste management 7(4), 224234.

Snyder S.A., Westerhoff P., Yoon Y. and Sedlak D.C. (2003b) Pharmaceuticals, personal care products and endocrine disrupters in water: implications for water treating. Environmental Engineering Science 20(5), 449-469.

Snyder E. M., Snyder S. A., et al. (2004a). Reproductive responses of common carp (Cyprinus carpio) exposed in cages to influent of the Las Vegas Wash in Lake Mead, Nevada from late winter to early spring. Environmental Science \& Technology 38(23), 6385-6395. 
Snyder S. A., Leising J., et al. (2004b) Biological attenuation of EDCs and PPCPs: Implications for water reuse. Ground Water Monitoring \& Remediation 24(2), 108-118.

Snyder S.A, Wert E., Edwards J., Budd G., Long B. and Rexing D. (2004c) Magnetic ion exchange (MIEX) for the removal of endocrine disruption chemicals and pharmaceuticals. American Water Works Association (AWWA) Water Quality and Technology Conference (WQTC 2004).

Snyder E. M., Pleus R. C., et al. (2005a) Pharmaceuticals and EDCs in the US water industry - an update. Journal American Water Works Association 97(11), 32-36.

Snyder S., Wert E., Westerhoff P., Yoon Y., Rexing D. and Zegers R. (2005b) Occurrence and treatment of endocrine disruptors and pharmaceuticals. Proceedings from the International Ozone Association $17^{\text {th }}$ World Congress, Strasbourg France August 22-25, 2005.

Snyder S.A., Wert, E., Yoon Y. and Wsterhoff P. (2006) Role of membranes and activated carbon in the removal of endocrine disruptors and pharmaceuticals during water treatment processes. Desalination, In press.

Stroud S. W. (1940) Metabolism of the parent compounds of some of the simpler synthetic estrogenic hydrocarbons. Journal of Endocrinology 2, 55-62.

Stull J.K., Swift D.J.P. and Niedoroda A.W. (1996) Contaminat dispersal on the Palos Verdes continental margin: I. sediments and biota near a major California wastewater discharge. The Science of the Total Environment 179, 73-90.

Stumm-Zollinger E. and Fair G. M. (1965) Biodegradation of steroid hormones. Journal of the Water Pollution Control Federation 37: 1506-1510. 
Summers R.S. and Roberts P.V. (1984) Simulation of DOC removal in activated carbon beds, Journal of Environmental Engineering 110 (2) 73-92.

Symons J., Fu P., Kim P. (1995) Sorption and Desorption Behaviour of Natural Organic Matter onto Strong-Base Anion Exchanger, Ch 4 in Ion Exchange Technology edited by Sengupta A., Technomic Publishing Co. Inc., Lancaster, PA, USA

Tabak H. H., Bloomhuff R. N., et al. (1981) Steroid hormones as water pollutants II. Studies on the persistence and stability of natural urinary and synthetic ovulationinhibiting hormones in untreated and treated wastewaters. Dev. Ind. Microbiol. 22, 497-519.

Tabak, H. H. and Bunch R. L. (1970) Steroid hormones as water pollutants. I. Metabolism of natural and synthetic ovulation-inhibiting hormones by microorganisms of activated sludge and primary settled sewage. Dev. Ind. Microbiol. 11, 367-376.

Tang C. and Chen V. (2002) Nanofiltration of textile wastewater for water reuse, Desalination 143 (1), 11-20.

Tchobanoglous G. and Burton F.L. (1991) Wastewater engineering: treatment, disposal, and reuse. $3^{\text {rd }}$ Eds., MaGraw-Hill, Inc. New York.

Tchobanoglous G., Darby J., Bourgeous K., McArdle J., Genest P. and Tylla M. (1998) Ultrafiltration as an advanced tertiary treatment process for municipal wastewater. Desalination 119 (1-3), 315-321.

Ternes T. A., Kreckel P., et al. (1999a) Behaviour and occurrence of estrogens in municipal sewage treatment plants - II. Aerobic batch experiments with activated sludge. The Science of the Total Environment 225, 91-99. 
Ternes T. A., Stumpf M., et al. (1999b) Behavior and occurence of estrogens in municipal sewage treatment plants - I. Investigations in Germany, Canada and Brazil. The Science of the Total Environment 225, 81-90.

Thanuttamavong M., Yamamoto K, Oh J.I., Choo K.H. and Choi S.J. (2002) Rejection characteristics of organic and inorganic pollutants by ultra low-pressure nanofiltration of surface water for drinking water treatment. Desalination 145, 257-264.

Thurman E.M. (1985) Organic geochemistry of natural waters. Martinus Nijhoff/Dr. W. Junk Publishers. The Netherlands

Tixier C., Singer H.P., Oellers S. and Müller S.R. (2003) Occurrence and fate of carbamazepine, clofibric acid, diclofenac, ibuprofen, ketoprofen, and naproxen in surface waters. Environmental Science and Technology 37 (6), 1061-1068.

Urfer D., Huck P.M., Booth S.D.J. and Coffey B.M. (1997) Biological filtration for BOM and particle removal: a critical review, Journal of American Water Works Association 89 (12), 83-98.

USEPA (2006) http://www.epa.gov/waterscience/criteria/wqcriteria.html

USEPA, (1997) Special report on environmental endocrine disruption: an effects assessment and analysis. Office of Research and Development. Washington, D.C. February 1997. EPA/630/R-96/012.

Vanderford B.J., Pearson R.A., Rexing D.J., and Snyder, S.A. (2003) Analysis of endocrine disruptors, pharmaceuticals, and personal care products in water using liquid chromatography/tandem mass spectrometry. Analytical Chemistry 75(22), 6265-6274. 
Vigneswaran S. and Visvanathan C. (1995) Water treatment processes: simple options. CRC press, Florida, USA.

Welch R. M., Levin W., et al. (1969) Estrogenic action of DDT and its analogs. Toxicology and Applied Pharmacology 14(2), 358-367.

Wert E.C., Edwards-Brandt J.C., Singer P.C. and Budd G.C. (2005) Evaluating magnetic ion exchange resin $\left(\mathrm{MIEX}^{\circledR}\right)$ pretreatment to increase ozone disinfection and reduce bromate formation. Ozone: Science and Engineering, 27, 317-379.

Westerhoff P., Yoon Y., et al. (2005) Fate of endocrine-disruptor, pharmaceutical, and personal care product chemicals during simulated drinking water treatment processes. Environmental Science \& Technology 39(17), 6649-6663.

Wingender J., Neu T.R. and Flemming H-.C. (1999) What are bacterial extracellular polymeric substances?. In: Wingender, J., Neu, T.R., and Flemming, H-.C. Editors, Microbial extracellular polymeric substances: characterization, structure and function, Springer, Berlin.

Yates III L.M. and Von Wandruszka R. (1999) decontamination of polluted water by treatment with a crude humic acid blend. Environ. Sci. Technol. 33, 2076-2080.

Yoon Y., Westerhoff P., Snyder S.A. and Wert E.C. (2006) Nanofiltration and ultrafiltration of endocrine disrupting compounds, pharmaceuticals and personal care products. Journal of Membrane Science, In Press,

Zhang R., Vigneswaran S., Ngo H.H. and Nguyen H. (2005) Magnetic ion exchanger $\left(\mathrm{MIEX}{ }^{\circledR}\right)$ as a pre-treatment to a submerged membrane system in the treatment of biologically treated wastewater. Desalination, In press.

Zhu X. and Elimelech M. (1997) Colloidal fouling of reverse osmosis membranes: measurements and fouling mechanism. Environmental Science and Technology 31, 3654-62. 